\title{
Managing and Reforesting Degraded Post-Mining Landscape in Indonesia: A Review
}

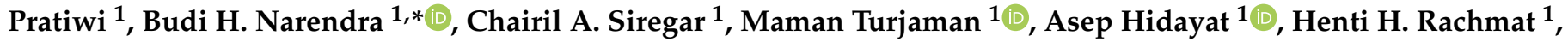 \\ Budi Mulyanto $^{2}$, Suwardi ${ }^{2}$, Iskandar ${ }^{2}$, Rizki Maharani ${ }^{3}$, Yaya Rayadin ${ }^{4,5}$, Retno Prayudyaningsih ${ }^{6}$, \\ Tri Wira Yuwati ${ }^{7}$, Ricksy Prematuri ${ }^{8}$ and Arida Susilowati ${ }^{9}$
}

\section{check for}

updates

Citation: Pratiwi; Narendra, B.H.; Siregar, C.A.; Turjaman, M.; Hidayat, A.; Rachmat, H.H.; Mulyanto, B.; Suwardi; Iskandar; Maharani, R.; et al Managing and Reforesting Degraded Post-Mining Landscape in Indonesia: A Review. Land 2021, 10, 658. https://10.3390/land10060658

\section{Academic Editors:}

Oimahmad Rahmonov,

Jacek Róźkowski and Grzegorz Kłys

Received: 24 May 2021

Accepted: 17 June 2021

Published: 21 June 2021

Publisher's Note: MDPI stays neutra with regard to jurisdictional claims in published maps and institutional affiliations.

Copyright: (C) 2021 by the authors Licensee MDPI, Basel, Switzerland. This article is an open access article distributed under the terms and conditions of the Creative Commons Attribution (CC BY) license (https:// creativecommons.org/licenses/by/ $4.0 /)$.
1 Forest Research and Development Center, The Ministry of Environment and Forestry, Jl. Gunung Batu No. 5, Bogor 16610, Indonesia; pratiwi.lala@yahoo.com (P.); siregarca@yahoo.co.id (C.A.S.); turjaman@gmail.com (M.T.); ashephidayat12@gmail.com (A.H.); hendalastuti@gmail.com (H.H.R.)

2 Faculty of Agriculture, IPB University, Jl. Raya Darmaga Km. 8, Bogor 16680, Indonesia; budi_mulyanto@apps.ipb.ac.id (B.M.); suwardi-soil@apps.ipb.ac.id (S.); issi_iskandar@apps.ipb.ac.id (I.)

3 Dipterocarp Ecosystem Research and Development Centre, J1. AW Syahrani No. 68 , Samarinda 75124, Indonesia; rizma_annisa@yahoo.com

4 Faculty of Forestry, Mulawarman University, Jl. KH Dewantara, Samarinda 75123, Indonesia; yrayadin@yahoo.com

5 Ecology and Conservation Center for Tropical Studies (Ecositrop), Komplek Talang Sari Regency Cluster Dahlia No. AA74, Samarinda 75118, Indonesia

6 Environment and Forestry Research and Development Institute of Makassar, Jl. P. Kemerdekaan Km. 16, Makassar 90243, Indonesia; rprayudyaningsih@gmail.com

7 Environment and Forestry Research and Development Institute of Banjarbaru, Jl. Ahmad Yani, Km. 28,7, Banjarbaru 70722, Indonesia; triwira@foreibanjarbaru.or.id

8 Research Centre for Bioresource and Biotechnology, IPB University, Jl. Raya Darmaga Km. 8, Bogor 16680, Indonesia; ricksy2789@gmail.com

9 Faculty of Forestry, Universitas Sumatera Utara, Jl. Tridharma Ujung No. 1, Medan 20155, Indonesia; arida.susilowati@usu.ac.id

* Correspondence: narendra17511@gmail.com; Tel.: +62-8124-203-265

Abstract: Tropical forests are among the most diverse ecosystems in the world, completed by huge biodiversity. An expansion in natural resource extraction through open-pit mining activities leads to increasing land and tropical forest degradation. Proper science-based practices are needed as an effort to reclaim their function. This paper summarizes the existing practice of coal mining, covering the regulatory aspects and their reclamation obligations, the practices of coal mining from various sites with different land characteristics, and the reclamation efforts of the post-mining landscapes in Indonesia. The regulations issued accommodate the difference between mining land inside the forest area and outside the forest area, especially in the aspect of the permit authority and in evaluating the success rate of reclamation. In coal-mining practices, this paper describes starting from land clearing activities and followed by storing soil layers and overburden materials. In this step, proper handling of potentially acid-forming materials is crucial to prevent acid mine drainage. At the reclamation stage, this paper sequentially presents research results and the field applications in rearranging the overburden and soil materials, controlling acid mine drainage and erosion, and managing the drainage system, settling ponds, and pit lakes. Many efforts to reclaim post-coal-mining lands and their success rate have been reported and highlighted. Several success stories describe that post-coal-mining lands can be returned to forests that provide ecosystem services and goods. A set of science-based best management practices for post-coal-mine reforestation is needed to develop to promote the success of forest reclamation and restoration in post-coal-mining lands through the planting of high-value hardwood trees, increasing trees' survival rates and growth, and accelerating the establishment of forest habitat through the application of proper tree planting technique. The monitoring and evaluation aspect is also crucial, as corrective action may be taken considering the different success rates for different site characteristics.

Keywords: open-pit mining; biodiversity; tropical forests; degraded land; reclamation 


\section{Introduction}

Mining is one of the most important economic sectors in Indonesia. Mining products contribute up to $17 \%$ per year of Indonesia's total export value, and from several major mining products, coal mining contributes a value of $87.27 \%$ [1]. Data from verified resources and reserves as of December 2019 showed that coal mining had the potential to reach $88,338.66$ and $25,070.50$ million tons, respectively. This potential was spread across 23 provinces with the greatest potential discovered in East Kalimantan, South Sumatra, and South Kalimantan [2].

Coal and mineral resources have an important role in Indonesian economic development [3]. Mining materials contribute around 5 percent to Indonesia's total gross domestic product (GDP) [4]. The Indonesian coal industry is one of the world's largest coal producers and exporters, while the production of other minerals is developing more slowly. The potential mineral deposits comprise ferrum and associates (iron, nickel, mangan, cobalt, titanium, chromite, and molybdenum), precious metals (gold, silver, and platinum), base metals (tin, zinc, copper, lead, and mercury), and rare metals (bauxite and monazite) [5]. However, almost all of the mineral and coal resource deposits in Indonesia are located in tropical rainforest lands [6].

Tropical rainforest lands carry the physical, chemical, and biological characteristics of the forest soils. They are naturally stable and resilient bodies that can be temporarily altered by natural driving forces like fire and flood [7]. However, the impacts of anthropogenic perturbations associated with extensive human activities, such as mining, on the soil's physical, chemical, and biological properties and the long-term sustainability happen to be one of the burning issues that have become global [8]. Many of the problems remain peculiar to the forest stakeholders and require a special effort to clarify the adverse experiences and in turn review the solutions to manage the difficulties.

Although the world's demand for renewable energy is growing and coal consumption fell $0.6 \%$ in the last six years, global coal use $(24.2 \%)$ is still the main energy source after oil [9]. Until now the coal industry has had a positive impact on Indonesia's economic growth and infrastructure development in remote areas. However, surface mining or open-pit mining techniques potentially harm the environment including extensive forest degradation, biodiversity loss [10,11], landslides, soil erosion, soil pollution from mining waste, and tailing dust [12], also leading to social conflicts [13].

Globally, many mining sites are located in forest areas, including in Indonesia, and reforestation is still considered the best choice in providing ecological and economic benefits [14]. Several national-scale mining companies (the distribution can be seen in Figure 1) have proven how they conduct post-mining landscape reclamation and reforestation activities, especially post-mining lands, which were originally a forestry area that was loaned to extract mining materials. The main problem in reforestation of post-mining sites refers to the degraded condition of forest tree growth ranging from high toxicity coming from different pollutants, lack of macro and micronutrients, organic matter, and disturbance of water regime in soils [15]. Reforestation activities that aim to return the sites to their original baseline condition become very unlikely [16]. Efforts to cover overburdened areas with hydroseeding technology are the first step to reduce surface erosion. The success of planting fast-growing tree species and some technological inputs to increase soil fertility has become the main direction for mining companies [17].

This paper evaluates the long-term results of managing and reforesting degraded postcoal-mining landscapes, and post-mineral mining as a comparison. As shown in Figure 2, the review carried out in this study includes current knowledge concerning the national policy of mining exploitation and reforestation in post-mining lands, the physical and engineering processes, and landscape management in post-mining lands. It also involved the biological aspects. These aspects are concerned with the strategy for selecting and planting forest tree species to encourage the reforestation of indigenous tree species and the rehabilitation of soil fertility in degraded post-mining lands; the development and the application of soil microbes, monitoring changes in plant and animal ecology, and the role 
of hydro-seeding technology for promoting cover crops and plant colonization in degraded post-mining lands.

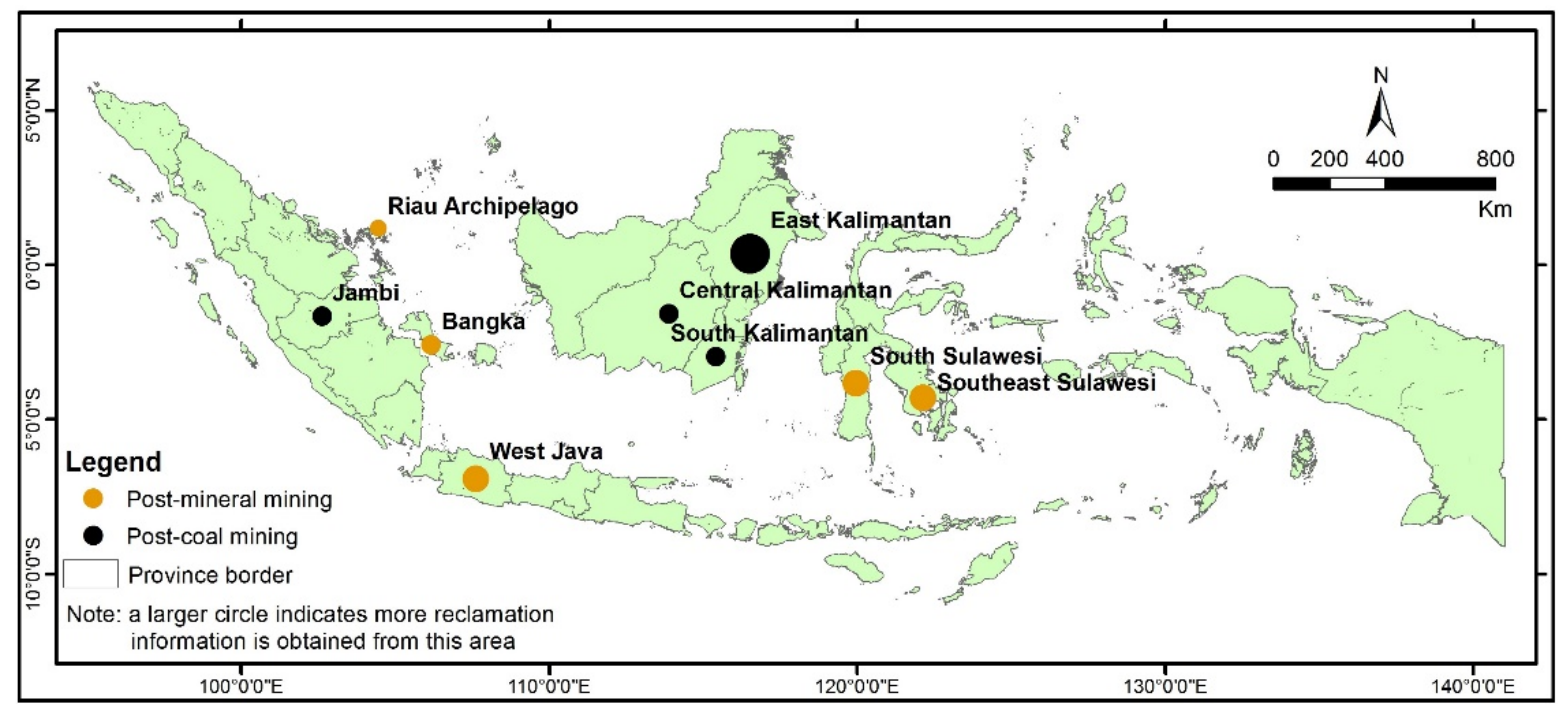

Figure 1. Some post-mining areas focused on in this study.

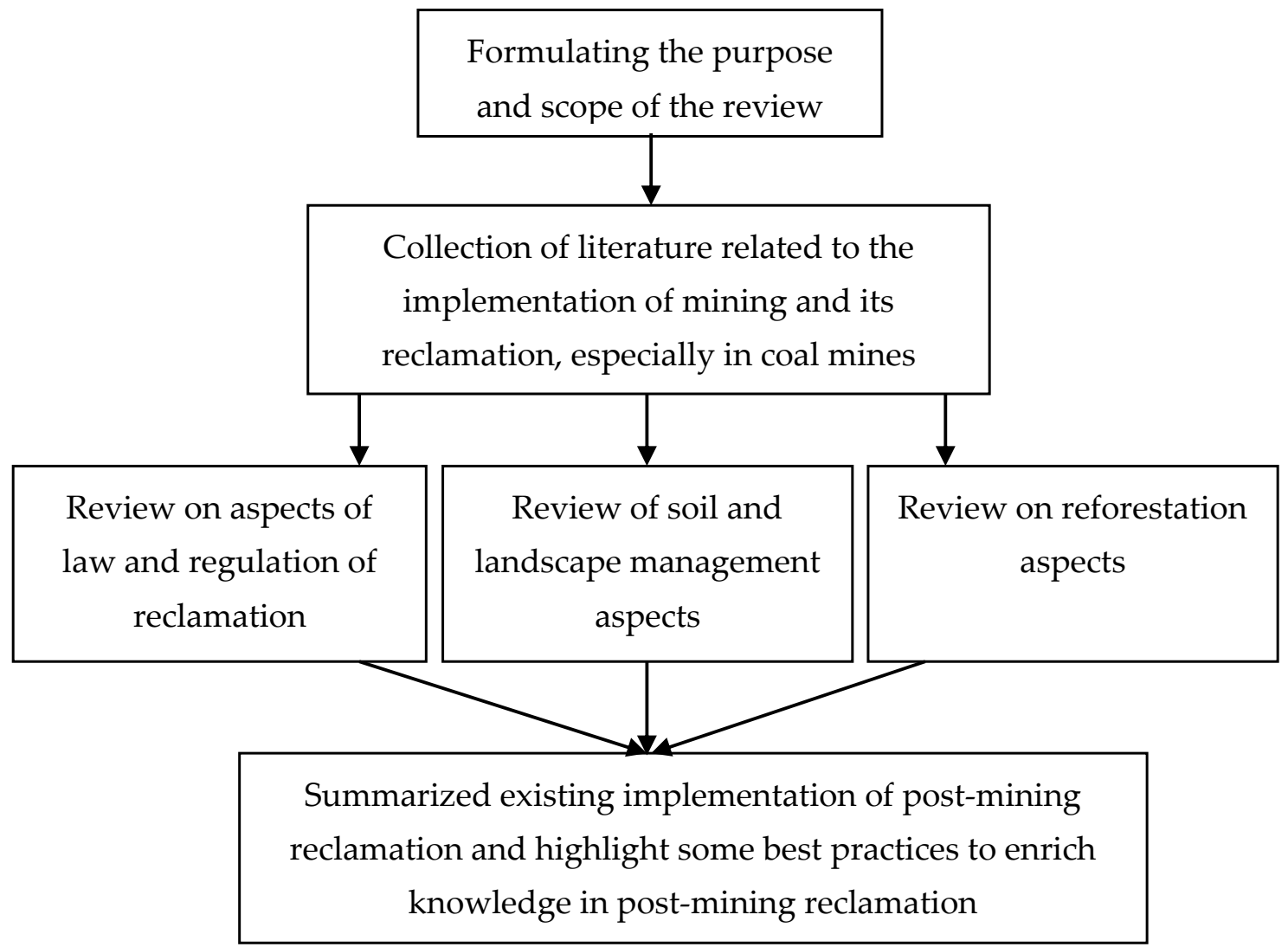

Figure 2. Stages in conducting the review.

\section{Law and Regulation of Mining in Indonesia}

Based on Government Regulation No. 78/2010 on Reclamation and Post-Mining [18], an effective reclamation program and reforestation of post-mining land are stated clearly, even with the closure of the mine [10]. Reclamation is the last stage in mining activities after the exploration and exploitation stages [19]. In this paper, the terminology of reclamation 
refers to activities to improve post-mined land conditions so that they can function again as originally intended or according to other productive uses that have been planned [20]. In general, the reclamation stage includes land structuring activities that are followed by revegetation activities [21]. The revegetation stage for reforestation became the focus of this paper.

Attention to the management and reforestation of land in post-mining landscapes is manifested by the issuance of laws and regulations related to mining and forestry. In 1967, Law No. 11 regarding Basic Provisions for Mining was published. This law was detailed into several derivative laws, including Law No. 4/2009, which was updated with Law No. 3/2020 regarding Mineral and Coal Mining [18]. In the forestry sector, Law No. 5 on Basic Forestry Provisions was issued in 1967, which was renewed by Law No. 41/1999 on Forestry [22]. The latest progress of regulations related to mining activities was the issuance of Law No. 11/2020 on Job Creation, Government Regulation No. 5/2021 on Implementation of Risk-Based Business Licensing, and No. 25/2021 on Implementation of Energy and Mineral Resources Sectors [18].

Law No. 3/2020 provides the Minister with the authority to issue Community Mining Permits. This is done, among other things, to overcome the rampant illegal artisanal and small-scale mining. The community mining permits are granted to local residents individually with a maximum area of five hectares or to cooperatives whose members are local residents with a maximum area of ten hectares. Both can be granted for a period of ten years and can be extended twice for five years each. Furthermore, Government Regulation No. 23/2010 regarding the implementation of mineral and coal mining business activities and Government Regulation No. 78/2010 on Reclamation and Post-mining [18] emphasized that the holders of Mining Business Permits and Special Exploration Mining Business Permits had to conduct reclamation.

A special regulation regarding the implementation of good mining principles and control of mineral and coal mining was issued by the Minister of Energy and Mineral Resources Regulation No. 26/2018 [18]. The regulation principally defined/controlled/managed how to explore and supervise mining, but not how to revegetate post-mining land. The governors also issued provincial regulations on how to manage mineral and coal mining, including regulations on reclamation and community mining. However, the definition of community mining was ill-defined. It resulted in the incorrect implementation of this regulation, which triggered illegal mining and abandoned the reclamation process. Weak legal sanctions, especially against community miners, have led to many violations that did not conduct the post-mining reclamation and further caused severe land damage [23]. The Indonesian Government has enacted various regulations requiring post-mining reclamation activities; however, there has not been much evaluation of these regulations in terms of the ecological concept of restoration [24].

Regarding the reclamation process, the government has issued various policies to ensure the compliance of every permit holder company with the existing regulations, including the existence of a reclamation guarantee fund. Reclamation plans are generally prepared before mining production activities begin. These plans are immediately implemented one month at the maximum after mining activities are finished in one site. It is necessary to rehabilitate post-mining land by integrating ecological [25-27] and economic factors for local communities such as production forests, plantation crops, and other factors [11,28].

The weak implementation of earlier regulations on reclamation forced the government to issue Law No. 3/2020 concerning mineral and coal mining. The latest law stipulates the obligations of mining concession license holders to execute a successful reclamation of post-mining lands and imposes sanctions on those who fail to reclaim their post-mining lands. The sanctions are in the form of imprisonment, fines, and withdrawal of their mining permits conducted by the provincial and regency/city governments.

There are significant concerns about the number of mining concessions that have been granted in the forest areas. According to Forestry Law No. 41/1999, forest areas managed 
by the state can be used for non-forestry sector activities [22], one of which is mining activities. The Indonesian Government, through Government Regulation No. 105/2015, regulates that mining activities are allowed to be operated in production forests, even in protected forests [22]. In the production forests, mining can be operated through open-pit mining or underground mining, while only underground mining is allowed in protected forests. Mining practices in these forest areas can be conducted through the issuance of a permit by the minister or known as a Leasehold License of the Forest Area (LLFA). The granting of this permit is regulated in the Minister of Environment and Forestry (MoEF) Regulation No. 27/2018. In January 2021, there were 1089 active LLFA holders with a total area of 482,223.63 hectares [29].

LLFA is a contractual relationship between the MoEF and the permit holder. The government, represented by the MoEF as the mandate grantor, has the position of the principal, while the permit holder is the agent who receives the mandate. As a recipient of the mandate, miners have the right to perform mining and utilize forest products according to the designated area [30]. LLFA regulates the size of the mining operation area, the period of the permit, the obligations of the permit holder, and other prohibited points.

One of the obligations of the permit holder is to plan and conduct reclamation according to the stages of mining activities. All mining permit holders are subject to reclamation provisions regulated in the Ministry of Energy and Mineral Resources (MoEMR) Regulation No. 7/2014 [18], while for the LLFA permit holders, the reclamation obligations are mostly based on the guidelines and standards issued by the Ministry of Environment and Forestry $(\mathrm{MoEF})$ in the regulation number 4/2011 [22]. Both regulations control the implementation of reclamation, started by the arrangement of annual and five-year planning.

A different emphasis can be seen in the reclamation assessment used by the MoEF. Although the components of the assessment from the two ministry regulations are relatively similar, the MoEF regulation emphasizes revegetation (50\%), which includes aspects of planting area, survival/success rate, and plant composition. In reclaiming ex-mining in forest areas, the regulations allow for the use of pioneer species, which generally consist of exotic and fast-growing species. However, the regulations do not particularly prohibit the use of invasive exotic species [24]. In determining the plant species, the wishes of the local community can be taken into consideration, especially those whose livelihoods depend on land resources. However, the composition of plant species still follows the regulation [30]. The final assessment of the reclamation implementation in a certain site will be evaluated by the government based on the Ministry of Energy and Mineral Resources (MoEMR) Regulation No. 7/2014, and for the LLFA holder, the evaluation will be guided based on Ministerial Regulation of Forestry number 60/2009 [22]

In some particular conditions, ex-mining lands will leave a final void. Based on the Government regulation, such areas, if it is not possible to reclaim/rehabilitate them, can be used for other purposes that benefit the community in terms of their environmental, economic, and social aspects [11]. Their uses must also be based on an environmental impact assessment so that they become suitable for aquaculture, provide clean water sources, and function as irrigation water sources or tourist attractions [31].

\section{Open Pit Mining Process and Landscape Management}

\subsection{Land Clearing}

Technical mining activities in Indonesia refer to the guidelines issued by the Directorate of Mineral and Coal Engineering and Environment, Ministry of Energy and Mineral Resources. As with other open-pit coal mining operations, before the coal extraction process can be executed, companies are required to peel, save, and temporarily store the layers of soil materials found to be reused as a plant growth medium in revegetation activities [32,33]. This soil stockpile is placed in a safe place, and if it is not used immediately, then the surface is planted with grasses or legume cover crops (LCC) to reduce possible erosion. In case the stockpiled topsoils stay for a long period, the physical, chemical, and biological nature of the topsoils may be degraded [34] until they have been spread as final 
layers on the surface of the reclamation area. Hence, the topsoils in the stockpile area should be managed properly. Soil materials, often called topsoil in mining, which can be used as plant growth medium according to SNI (Indonesian National Standard) 6621: 2016, are soil materials originating from horizons $\mathrm{A}$ and $\mathrm{B}$, and can also include horizon C if they are considered suitable as planting media. The principles used in the management of topsoil are (1) using it as soon as possible in reclamation activities, (2) keeping it safe from erosion and sedimentation, and (3) improving the quality of soil fertility.

The handling of overburden $(\mathrm{OB})$ material or waste rocks is also important to determine whether they are categorized as NAF (non-acid forming) or PAF (potentially acid-forming) materials [35], as both materials have different characteristics. OB-PAF is waste rocks containing sulfide minerals. When OB-PAF is exposed to water and air, an oxidation reaction will form, which will generate sulphuric acid known as acid mine drainage (AMD) [36,37]. Therefore, OB-PAF must be stacked and placed separately from OB-NAF. The sampling method, sample preparation, and OB material characteristic test are described in SNI 6597:2011, while the stacking procedure including monitoring is described in detail in SNI 7082:2016 regarding the procedure for stacking overburden to prevent the formation of acid mine drainage in coal open-pit mining activities. In SNI 6597:2011, the characteristics of OB materials are divided into four types, i.e., nonacid-forming, low-capacity acid-forming potential, high-capacity acid-forming potential, and acid-forming.

\subsection{Landscaping}

\subsubsection{Overburden Materials Placement and Acid Mine Drainage Control}

Reclamation of ex-mining land is carried out by following the Guidelines for Reclamation of Post-Mining Land issued by the Ministry of Energy and Mineral Resources (Director General of Mining Circular No. 3043/20/DJP/1993) and the Decree of the Minister of Energy and Mineral Resources No. 1827K/30/MEM/2018 concerning Guidelines for Environmental Implementation of Mineral and Coal Mining [18]. Reclamation activities begin with landscaping, which is rearranging all the remaining mining materials in the designated location with a calculated slope and thickness. The placement of OB materials according to their geochemical characteristics is one of the most important activities in this landscaping process. Some of the materials are categorized as OB-PAF, which can cause AMD problems in the future [38,39]. As OB-PAF turns out to be AMD, the high acidity condition will adversely affect the chemical nature of surface water in the vicinity, resulting in poor water quality to support the living organism in the soil [40]. The high acid conditions cause heavy metals present in the coal such as $\mathrm{Fe}[41], \mathrm{Hg}, \mathrm{Cd}, \mathrm{Pb}, \mathrm{Cr}, \mathrm{Cu}$, $\mathrm{Zn}$, and $\mathrm{Ni}$, which can be dissolved and carried to the waters fast [42].

To avoid the formation of AMD, generally, OB-PAF is stacked in a designated place and then encapsulated with other materials, such as OB-NAF materials or limestone. The materials are then compacted to prevent water infiltration and oxygen reaction with sulphidic minerals contained in OB-PAF materials [35,37]. Research in the Lati coal mine [43] as well as in the Sangatta and Bengalon coal mines [44] showed that encapsulation is the most effective method in preventing AMD. With the increasing use of coal as an energy source, the amount of coal combustion ash (CCA) produced has also increased. This CCA has a great potential to be used as a dry cover for OB-PAF materials $[45,46]$. The existence of AMD can be handled in two ways, active and passive handlings [35-37].

Most large mining companies in Indonesia have implemented an integrated approach to managing AMD in their mine sites. This approach includes the development of a geochemical model of OB or waste rock, AMD prevention through encapsulation of OBPAF material, and active as well as passive treatment methods [43,47,48]. In addition to active treatment using lime, several coal mines have also prepared constructed wetland areas to carry out passive treatment using various plant species to reduce Fe and Mn levels, as well as to increase $\mathrm{pH}$. Plants that have been studied intensively are purun (Eleocharis 
dulcis) [49,50], Fimbristilys hispidula, Mariscus compactus, and Typha angustifolia [51], and Eichhornia crassipes [52].

\subsubsection{Soil Materials Placement and Mine Soil Characteristics}

OB materials are very difficult to use directly as a growing medium due to their chemical-physical properties that are not suitable for plant root growth. OB materials are structureless with high bulk density due to the movement of heavy machinery and often contain an elevated concentration of traced metals. Their characteristics hamper water circulation, limiting their capability to support the growth of plant roots [53,54]. Therefore, sowing topsoil over the arranged OB materials will serve as a growing medium for revegetation plants $[55,56]$.

In general, the soil thickness sown over OB materials ranges from $50-125 \mathrm{~cm}$. However, due to the thinning of the native soil [57] in the site, in several reclamation areas, the thickness of sown soil was only $10-80 \mathrm{~cm}$. This soil mixture was reported to have very low levels of organic $\mathrm{C}$, total $\mathrm{N}$, and available $\mathrm{P}$, was poor in other plant nutrients, and decreased the activity of microorganisms [58-60]. However, according to [61], the productivity of reclaimed sites after mining significantly depends more on the physical nature of the mine soils as compared to their chemical nature. Therefore, soil amendments with various materials available around the mine site to recover physical and chemical characteristics of the mine soils need to be performed by using, for instance, composted chicken manure, sawdust, lime, or NPK fertilizers [62-64].

\subsubsection{Revegetation Process}

Landscaping activities, especially the arrangement of $\mathrm{OB}$ materials followed by sowing of soil material as a plant growth medium over the surface of the final reclamation land, are very costly. According to [56], the most commonly accepted way to keep mine soil from being degraded by erosion during the reclamation process is through revegetation. For Indonesian conditions, the commonly used revegetation plants are fast-growing pioneer plants. Revegetation in ex-mining lands not only protects the mine soil from degradation due to erosion but also improves the quality of the mine soil itself. Improving the quality of mine soil does not solely come from trees but also from the legume cover crops (LCC).

Revegetation not only improves the quality of the mine soil but also the microclimate conditions. Revegetation makes the land surface become covered by plant canopy, and the percentage of the cover becomes denser with the increasing age of the revegetated plants. As revegetation trees grow over time, the microclimate of the reclaimed sites also changes, as indicated by a lower light intensity on the ground, a lower air temperature, and a relatively higher humidity [65-67]. A more detailed explanation of revegetation activities can be found in Section 4 .

\subsubsection{Erosion Control}

In Indonesia, as a humid tropical country, the rain falls evenly throughout the year with a fairly high average monthly rainfall. The high rainfall intensity during the wet season can lead to erosion and landslides in reclamation areas, which always become a major concern to control. To overcome this condition, the Ministry of Energy and Mineral Resources issued Technical Guidelines for Erosion Control in General Mining Activities (Decree of the Director-General of General Mining No. 693.K/008/DDJP/1996), which contains erosion control techniques, both vegetatively and civil engineering [18]. Due to the materials that formed the reclamation area were often dominated by fine earth-sized fractions that were easily eroded by water flow; waterways were reinforced with rock blocks or used tires, as shown in Figure 3. Escarpments formed due to terrace construction or morphological changes due to the construction of waterways are stabilized with rock blocks, rip-rap, or gabions. 


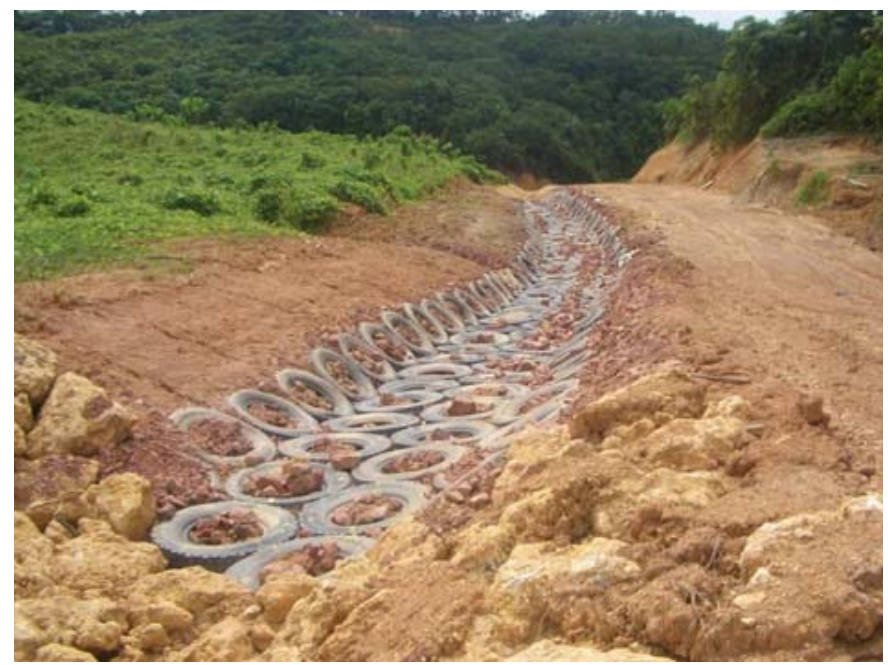

Figure 3. The drainage system constructed and reinforced with stone or other materials to reinforce the drain base.

The critical phase occurs when the soil material has been spread over the final surface but the revegetation plants are still small and the LCC has not grown to cover all the land surface. Therefore, a combination of LCC, grass, and local upland rice that can quickly cover the soil surface is highly desirable (Figure 4).

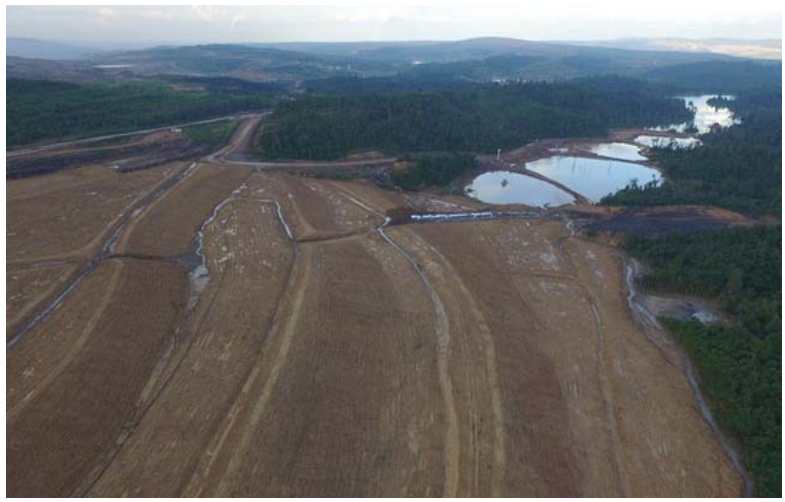

(a)

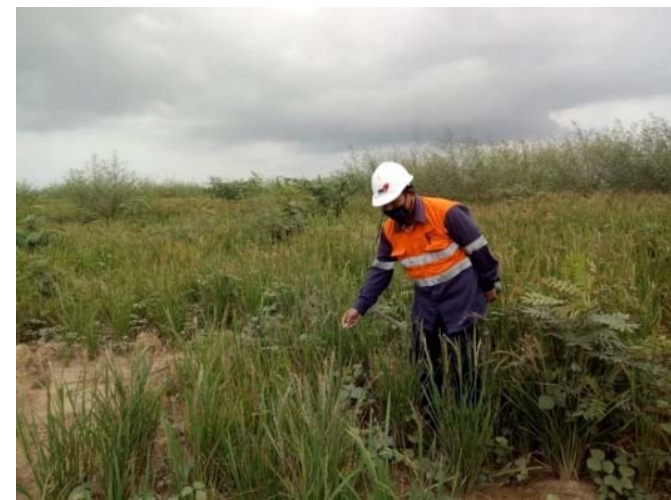

(b)

Figure 4. (a) The critical phase of the final surface against erosion and landslides after reclamation; (b) use of local upland rice and legumes as land cover crops to reduce the risk of erosion. Photo by Kaltim Prima Coal.

The amount of erosion in reclamation areas varies greatly depending on the age and success of the reclamation. Using the USLE equation, research in 17 coal mine reclamation areas in Kutai Kertanegara district, East Kalimantan [57], found that erosion rates in reclamation areas aged $<1$ year ranged from 36.5 to more than 4900 tonnes ha ${ }^{-1}$ year $^{-1}$, in areas aged 1-5 years erosion rates ranged from 1.9 up to 341.0 tonnes $\mathrm{ha}^{-1}$ year $^{-1}$, and in areas $>5$ years, erosion rates ranged from 2.1 to 201.1 tonnes ha ${ }^{-1}$ year $^{-1}$. High erosion rates in older reclamation areas usually occur in areas where revegetation plants do not grow optimally due to a lack of plant maintenance. Regarding the use of the USLE equation to calculate the amount of erosion in the reclamation area, the use of this equation in reclamation areas requires sufficient consideration because the conditions are very different from the conditions used in USLE, namely predicting soil loss in forest areas [68]. USLE was developed for agricultural watershed areas in America with data originating from America as well [69]. In contrast to Zulkarnain et al. [57], which states that the cause of high erosion in this reclamation area is soil compaction, which causes a decrease in the rate of soil permeability so that run-off increases, Hamanaka et al. [70] state 
that the causes of high erosion include unfavorable soil physical property of upper layer reclamation surface as affected by an uneven mixture of mine soils with $\mathrm{OB}$ materials, and as a result, the soil erodability turns to be somewhat high.

Because the erosion rate measured by the USLE equation approach often yields very high values, according to the advice of regulators some companies combine erosion measurement methods using erosion sticks (Figure 5). Erosion sticks are measured at a certain period, for example, two times a year. The actual erosion value is calculated from the height difference between the two measurements. The results of the 2017 erosion measurement using this method in Lati, Sambarata, and Binungan coal mines show that the average soil loss is less than $1 \mathrm{~mm}$ year ${ }^{-1}$, lower than the tolerable erosion rate of $1-2 \mathrm{~mm}_{\text {year }}{ }^{-1}$. In the $<2$-year-old revegetation area with poor cover conditions, the measured erosion was the highest, but the category was still very low [71].
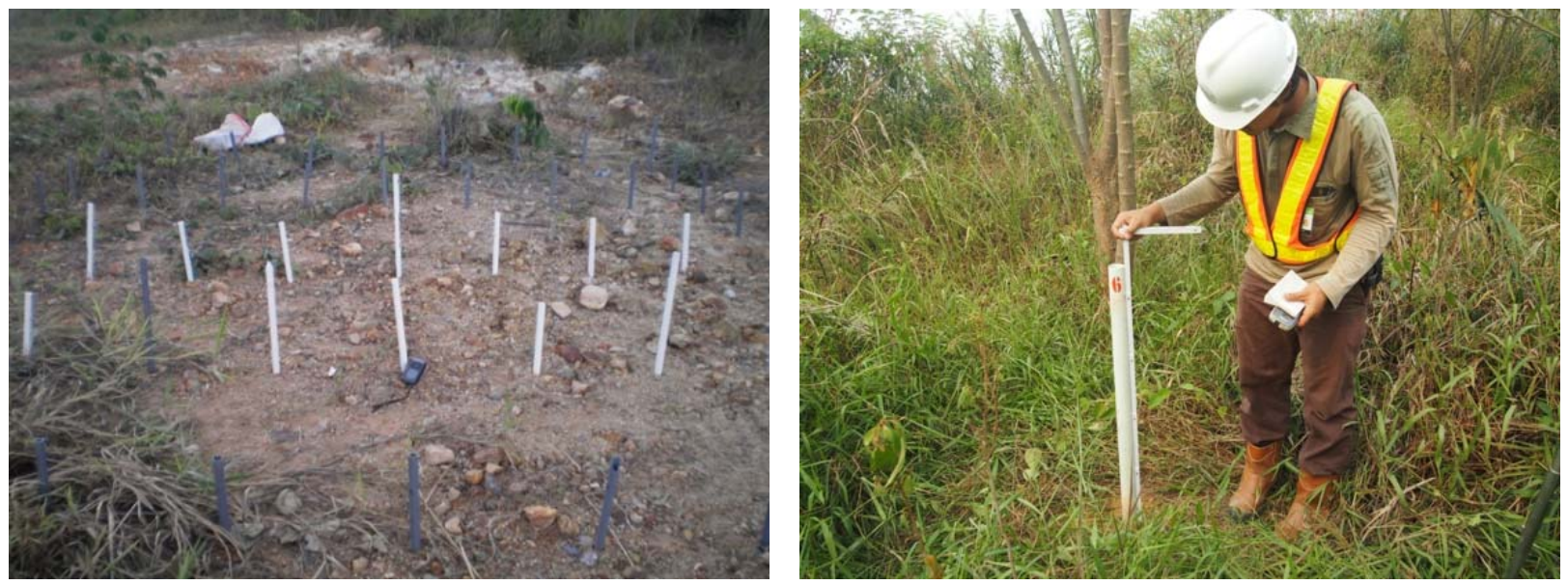

Figure 5. Measurement of the rate of erosion using erosion sticks. Photo by I. Iskandar.

\subsubsection{Drainage System and Settling Ponds}

Open-pit coal mining operations have caused a large part of the land surface to be exposed. The operations can have substantial environmental impacts not only on the undisturbed land surface, but also on piles of waste rocks, pit walls, and other mining facilities, such as hauling roads. The exposed soil surface is very susceptible to erosion, and uncontrolled management will lead to other problems such as polluting the nearest rivers [72]. To improve water quality outside the mine site, the local government issued a regulation regarding the environmental quality standard (EQS) of liquid waste from coal mining industries. According to Minister of Environment Decree number 113/2003 [22], the EQS of liquid waste from these industries has to have a $\mathrm{pH}$ characteristic of 6-9, a suspended residue of $400 \mathrm{mg} \mathrm{L}^{-1}$, a total Fe $7 \mathrm{mg} \mathrm{L}^{-1}$, and a total $\mathrm{Mn} 4 \mathrm{mg} \mathrm{L}^{-1}$. To comply with this regulation, companies flow their water, which generally comes from rainwater and a sump pit, to the calculated settling ponds to reach the EQS within a certain time. Adjusted to the characteristics of the local location, for example, a coal mining company in East Kalimantan built a configuration of two types of settling ponds, namely dam blocking with a dry dam concept and a labyrinth pond. Dry dam ponds were built to regulate the outflow, while labyrinth ponds were made as settling ponds. The company claimed that this method was effective and efficient in controlling water flow discharge at a relatively low and constant level, as well as facilitating the maintenance of settling ponds [73]. In addition to dry dam ponds and labyrinth ponds facilities, several companies have also added constructed wetland area facilities to increase $\mathrm{pH}$ and reduce Fe and Mn levels in AMD to meet the required EQS. A coal mining company in South Sumatra uses aquatic plants such as Fimbristilys hispidula (Vahl) Konth, Mariscus compactus (Retz) Druce, and Typha angustifolia L. [51,74]. The addition of constructed wetland facilities in coal mines that 
produce AMD needs to be done to anticipate the post-mining period, and the company has stopped controlling AMD with the active method.

The general regulation regarding wastewater is to reach the expected EQS, which is the particle settling time that is longer than the predicted results of the calculation. Therefore, to precipitate colloidal particles from the suspension, a larger settling pond or the use of chemical flocculants is required. The problem that usually arises after the construction of the settling pond is the maintenance and rehabilitation of this facility [69]. Aluminum $\left(\mathrm{Al}_{2}\left(\mathrm{SO}_{4}\right)_{3}\right)$, ferric sulfate $\left(\mathrm{Fe}_{2}\left(\mathrm{SO}_{4}\right)_{3}\right)$, ferric chloride $(\mathrm{FeCl} 3)$, and polyaluminum chloride or PAC $\left(\mathrm{Al}(\mathrm{OH}) 1.5\left(\mathrm{SO}_{4}\right) 0.125 \mathrm{Cl1} .25\right)$ are the most commonly used inorganic flocculants [75]. The use of biocoagulant seeds of Moringa oleifera showed promising results to reduce TSS, total Fe, and total Mn [76].

\subsubsection{Ex Mine Pit Management}

The open-pit coal mining system produced a mine hole that could not always be returned to its previous condition. When the bottom of the hole was below the natural groundwater level, and when the dewatering process had also been stopped, the pit was soon be filled with groundwater, rainwater, and surface runoff from the surrounding area. A pit lake was formed when the former mine pit was filled with water [77]. The existence of these pit lakes was often seen as a significant long-term risk to health, safety, and the environment, which was often difficult to overcome, such as poor water quality (high levels of metals and acidic $\mathrm{pH}$ due to oxidation of sulfide minerals), unstable and steep slopes, risk of landslides, and high risk of sinking [78,79]. However, if managed properly, pit lakes could also be used for various purposes, such as recreation areas, natural conservation, fisheries, industrial water sources, raw materials for drinking water, protection against flood hazards, and of course education and research purposes. EQS for water quality refers to Government Regulation No. 82/2001 concerning Water Quality Management and Water Pollution Control, while the water utilization regulations refer to Government Regulation No. 121/2015 concerning the Exploitation of Water Resources [22], which among other things obliges companies not to interfere with, override, or negate people's rights to water, and so on. Ex-mining pits must also meet the requirements as stated in the Decree of the Minister of Energy and Mineral Resources 1827K/30/MEM/2018 concerning Guidelines for Environmental Implementation of Mineral and Coal Mining, which covers the main criteria: slope stabilization, safeguards, restoration, and monitoring, as well as management according to the designation, and maintenance of post-mining pits [18]. Some examples of the use of pit lakes are described further in Section 4.4. Evaluation of Reclamation Process.

\section{Reforestation Process}

Surface mining has a major impact on forest soil and the landscape that requires a large effort to recover the ecosystem from [80], which may lead to different conditions from its initial condition. The reclamation of post-mining land in Indonesia is mandatory for all mining companies that have been instructed to shorten the time of recovery and to accelerate the natural succession process to support successional stages to their nearly initial condition. The following section will discuss reforestation attributes that define the success rate of post-coal-mining activities in Indonesia, including species selection, producing adaptable planting stocks, planting, tending, monitoring, evaluation, and several successful stories.

\subsection{Species Selection}

Species selection is a crucial step that harmonizes different aspects of planting objectives, species-site suitability, tree products, and ecological effects [81-84]. As the postmining lands showed extreme environmental impacts, the selected species were recommended to be fast-growing, highly resistant to drought, and tolerant of unfavorable conditions [56]. Thus, at the initial stage of the reforestation, pioneer species that have been 
widely applied in various reforestation schemes were planted, followed by other shadetolerant species, to create a more suitable environment.

Reforestation with local/native tree species was more prioritized than those of exotic ones; however, both groups had their advantages and disadvantages to consider in selection [85]. In Indonesia, there has been a record of 163 local prominent tree species that could be developed in the reforestation program, because their silvicultural aspect has been well known and widely practiced [81]. The combination between local prominent trees and fast-growing or pioneer species was highly recommended to gain higher success.

Among reforestation planting attributes, the provision of a more friendly environment to support the growth of higher plants is critical. Planting cover crops has immediate benefits in that they cover the soil surface, improve soil characteristics and protect the soil from erosion [86-89], reduce soil compaction [90,91], improve hydraulic conductivity, increase soil porosity [92], and enrich soil organic matter and macro- and microelements [93]. These crops further create a favorable environment for the growth and diversity of soil microbes [94]. In Indonesia, planting cover crops has been a mandatory activity conducted by all mining companies as stated in the regulation of the Minister of Forestry and the Minister of Energy and Mineral Resources.

Species that are often used are from the Fabaceae family or better known as the legume cover crops (LCC) such as Calopogonium mucunoides, Pueraria javanica, Centrosema pubescens, Crotalaria juncea, Calliandra tetragona, Mucuna cochinchinensis, and Mucuna bracteata [95,96]. On marginal tin mined overburden, the $P$. javanica has an advantage over $C$. mucunoides in terms of biomass growth and soil cover velocity [97]. In South Sumatera's post-coal-mining lands, the bokashi treatment resulted in greater growth and biomass for $C$. mucunoides compared to C. pubescens and P. javanica. On the other hand, C. pubescens provided the best influence on soil nutrients [98]. P. javanica, C. pubescens, and C. mucunoides significantly increased levels of $C$ and $N$ in the soil. Organic $C$ levels at a soil depth of 5-10 cm increased from $1.63 \%$ in the control to around $2.56-5.05 \%$ in the LCC treatment, while the levels of total $\mathrm{N}$ increased from $0.10 \%$ in the control to $0.25-0.27 \%$ in the treatment with LCC [58]. However, many LCC species are climbing plants that, if not maintained regularly, often disturb tree growth [87]. As an alternative, several species of non-climbing LCC can be an option, such as Desmodium spp. which is drought resistant, effectively suppresses weeds, and has the potential to fix substantial amounts of nitrogen [99]. Among the Desmodium genus, $D$. heterophyllum had a higher speed in covering the soil surface in post-coal-mining areas indicated by the plant-biomass growth rate of $5.02 \mathrm{~g} \mathrm{~m}^{-2} \mathrm{day}^{-1}$. This species also had a positive interaction with the planted wood seedlings, which significantly increased the diameter, height, and the number of leaves of jabon (Anthocephalus cadamba) seedlings [100].

Apart from LCC, the species that are often used as cover crops are grass species. Compared to LCC, grass cover crops have a deeper root system, and certain species have a better ability than LCC to grow and control weeds. However, the problem that is often faced with grass cover crop applications is the high $\mathrm{C} / \mathrm{N}$ soil ratio due to the low soil nitrogen, especially when the grass reaches maturity. This condition can be overcome by applying a combination of LCC and grass [101]. Vegetation analysis conducted in post-coal-mining lands in East Kalimantan showed several grass species such as Paspalum conjugatum and Saccharum spontaneum had the potential to be used as the cover crop because of their ability to grow naturally. P. conjugatum had the advantages of drought and shade resistance [102], and it was very good as phytoremediation, because it significantly reduced the content of $\mathrm{Cd}$ and $\mathrm{Pb}$ in the soil and was effective in increasing soil bacterial diversity [103]. S. spontaneum is a perennial grass that is naturally able to grow on land with extreme conditions such as high-sulfur coal mine overburden. It has broad and dense roots so that it is effective in suppressing erosion and has a high potential for biomass production as the source of fiber and bioethanol [104].

The sowing of cover crops on post-coal-mining land used the traditional sowing methods by humans. However, several coal mining companies used hydroseeding methods. The spreading cover crop seed on the soil surface was applied by using hydroseeding 
technology, especially on steep slopes or rough terrain, where the use of other equipment was difficult [17]. In comparison with the traditional sowing of spraying the LCC and grass by humans, the hydroseeding technology was more beneficial in terms of fast and homogeneous application, representing a reasonable choice for planting among other soil engineering methods [105]. The materials for hydroseeding application on post-coalmining landscapes in Indonesia involved a mixing mulch of wood fibers, local microorganisms, adhesive, compost, charcoal, and ash, or a mixing mulch of tackifier agent, water, compost, rice husk, sawdust, and urea. In some coal mining companies, the hydroseeding technique was used for planting pioneer plant seeds, such as the genera of Leguminosae, Poaceae, and Cyperaceae. The hydroseeding technique could be used for planting species of Leguminosae (Cajanus cajan, Crotalaria pallida, D. triflorum, Indigofera spicata, Sesbania grandiflora), Poaceae (Eleusine indica, Sporobolus indicus, P. conjugatum), and Cyperaceae (Cyperus brevifolius, C. odoratus, Kyllingia monocephala) in Tanah Laut, South Kalimantan, Indonesia [106]. This technique was applied and combined with a jute net for planting C. mucunoides, C. pubescens, and P. javanica, on the steep slope, where it was difficult to replant it, where the soil was easily eroded by rainwater due to the coal exploitation process [107]. The hydroseeding application on post-coal-mining landscapes is presented in Figures 6 and 7.

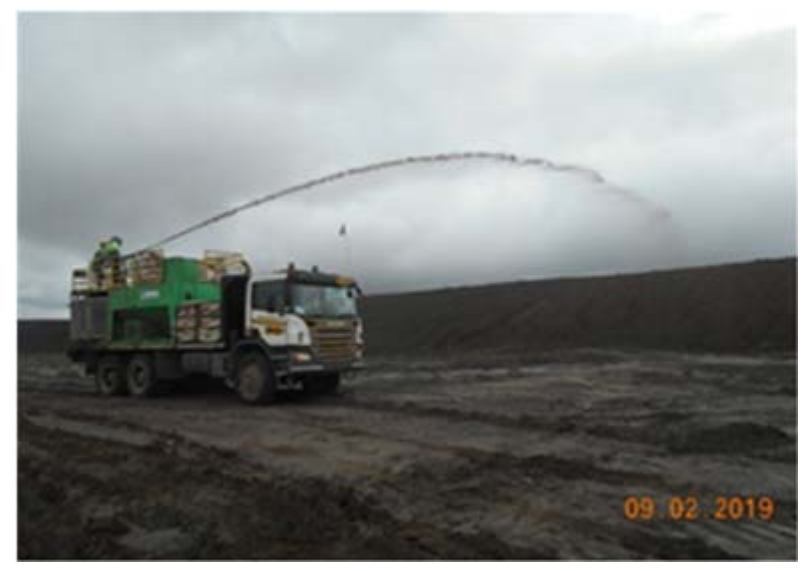

Figure 6. Hydroseeding application on post-coal-mining landscapes.

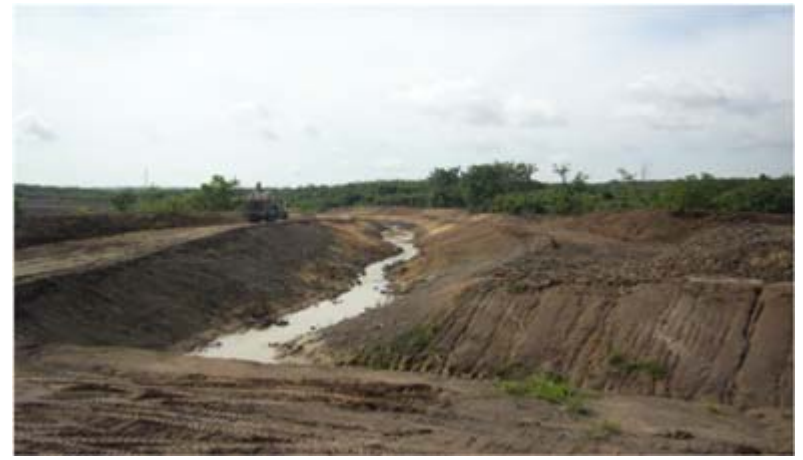

(a)

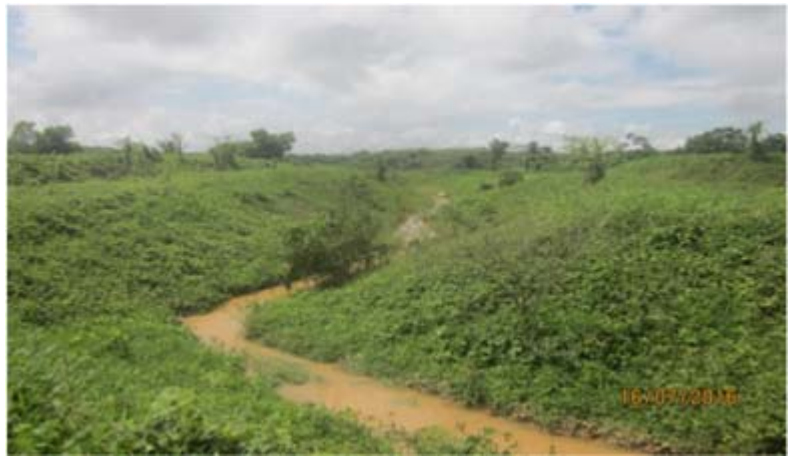

(b)

Figure 7. Post-coal mining before (a) and after (b) hydroseeding.

\subsubsection{Fast Growing/Pioneer Species}

In general, a reforestation process is initiated by selecting plants resistant to drought or fast-growing fodder crops that can grow with limited nutrients [56]. Fast-growing species can produce rapid growth, as the rapid closure of vegetation is important in controlling site stabilization, runoff, and erosion [108]. 
The adaptability of an individual tree species to the habitat conditions in reclaimed land and its ability to change the soil substrate characteristics is important to determine the optimal restoration strategies [54,109-114]. Considering the differences in their adaptability to a reclaimed site characteristic, tree species are classified as pioneering, target, climax, or late-successional species [111,115].

Pioneer species play an important role in initiating more habitable conditions for more demanding late-successional species. Naturally, the pioneer tree species can survive in minimum substrate conditions and hydrological ecology disruption and facilitate the subsequent vegetation. Thus, the pioneer species generally have small seeds that can easily spread by wind. Contrary to the pioneering species, climax species typically have large seeds and can be propagated vegetatively with different techniques [116-119]. In general, a revegetation strategy using pioneering species is related to the support provided for the initial condition of natural succession, which provides a more friendly environment for other targeted plant species [114-120]. Thus, the pioneer species creates micro and macro environments of post-coal-mining landscapes, so the environment becomes more stable and habitable.

Reforestation using pioneer, fast-growing, and adaptive plants such as Paraserianthes falcataria, Acacia sp., Peronema canescens, Gmelina arborea, Pterocarpus indicus, Jatropha curcas, and legume cover crops (LCC) in post-coal-mining land at Berau East Kalimantan had a significant effect on increasing the content of C-organic, $\mathrm{N}$-total, and soil $\mathrm{pH}$. After 5 years of reforestation, there was an improvement in soil chemical properties compared to conditions in wet tropical forests before open mining was executed [121]. Thus, later-stage species such as Artocarpus sp., Mangifera sp., and Eusideroxylon zwageri could be planted, as the microhabitat was able to support the growth of the later-stage species [122].

The multicultivation technique that mixes planted species between pioneer andfastgrowing (e.g., Macaranga gigantea, Cananga odorata, Geunsia petandra, Gironniera nervosa, and Paranephelium sp.) with local/native species (e.g E. zwageri, Durio sp., Shorea spp., Dipterocarps species) is the common practice in reforesting the post-coal-mining areas. To some extent, the mixture between native and non-native species was also a common technique practiced at the field scale. Reforestation by planting P. falcataria, Acacia mangium, A. auriculiformis, M. gigantea, Vitex pinnata, P. canescens, and Gliricidia maculata showed some success in survival rate and increasing the canopy cover in a post-coal-mining site in East Kalimantan [96]. Through a similar technique of mixing native and non-native, Vitex sp., P. canescens, Artocarpus heterophyllus, and A. mangium also showed a high survival rate of more than $80 \%$ [123]. Reforestation with non-native fast-growing pioneer legume species of Pongamia pinnata and the application of AMF drastically improved some chemical soil properties, such as an increase in the soil $\mathrm{pH}$ and total $\mathrm{N}$ soil content, which was suitable for a reclamation program in tropical post-mining areas. While the fast-growing pioneer legume species were proven to enhance the soil $\mathrm{N}$ supply by as much as 9-27 times, humus layer production accelerated the carbon cycle [41].

\subsubsection{Local/Slow-Growing Species}

The use of local plant species in the reforestation of post-mining areas is very important. The selection of local species is prioritized over exotic species, because local species are likely to be suitable and are able to adapt to the local climate [53]. Local species are more adaptive to local environmental conditions, as they have a catalytic effect and maintain the purity of biodiversity. It is also possible to grow them, as the seeds are more commonly available and the local people are more familiar with these local species. Local species also produce litter that decomposes easily and naturally, which functions to improve soil character and increases the thickness of the soil and as a conductive medium for the colonization of other plants. Another function of local plants is as a nurse plant, helping to facilitate the growth of other plant species, and they have better resistance to climate change $[124,125]$. Eventually, a healthier ecosystem can be established when the 
reforestation in post-mining land uses native/local species [126]. Local species are usually grown in post-mining areas after the microclimate is favorable for their growth.

In Indonesia, some native species that were planted in post-coal-mining areas were Dryobalanops sumatrensis, D. oblongifolia, Duabanga moluccana, Dyera costulata, Eusideroxylon zwagerii, Ficus racemosa, Neonauclea purpurea, Neolamarckia macrophylla, Palaquium gutta, Shorea lamellata, S. balangeran, S. smithiana, S. leprosula, and Vitex pinnata. However, S. lamellata, S. balangeran, D. moluccana, P. gutta, D. oblongifolia, and N. macrophylla were the species most known for their survival and adaptation to different habitat conditions for the reforestation of post-mining areas [127]. Some local permanent tree species in Indonesia have already been determined, and it is highly recommended that the development of these species, although they are slow-growing, is ecologically suitable, economically valuable, and socially acceptable [81]. The study in a post-coal-mining area of South Kalimantan showed that there were approximately 38 emerging species at 5 years after revegetation with Acacia mangium, A. auriculiformis, and P. falcataria. The dominant seedling species were Chromolaena odorata, Clibadium sp., and Melastoma sp., and the dominant tree species were Neonouclea sp., Vitex cofassus, A. auriculiformis, Combretocarpus sp., and Lohidion sp. [128]. Moreover, a study in South Kalimantan also showed that there were 89 species emerging on the post-coal-mining area of PT Adaro Indonesia 2 years after revegetation [129]. Another study has examined the succession acceleration in the forest revegetation aged six years, 10 years, and 12 years at the post-mining area of Kaltim Prima Coal, Sangatta, East Kalimantan. There were 19 tree species emerging under those stands dominated by Macaranga triloba, Homalanthus populneus, and Melastoma malabatrichum. The seedling density ranges from 2000-7500 seedlings $\mathrm{ha}^{-1}$ and the sapling density ranges from 1000-3000 saplings $\mathrm{ha}^{-1}$. It is emphasized that natural succession for revegetation after mining will take place after 6 years [130]. The study in the post-coal-mining area of PT Multi Harapan Utama East Kalimantan showed that after 5 years of revegetation, pioneer species naturally emerged, such as Cleistanthus myrianthus, Croton argyratus, Macaranga lowii, M. trichocarpa, and Neolamarckia cadamba [96]. Those species mentioned in four references are all early-stage species that will form the secondary forest.

Revegetation activities with pioneer species and local species in post-coal-mining sites require appropriate planting strategies. This planting strategy includes planting preparation, plant maintenance, and plant monitoring. In addition, each mining location has certain conditions that can affect the implementation of reclamation. For this reason, it is necessary to identify the initial needs of the land to determine the types of plants to be planted for revegetation of post-mining land. Several planting strategies that have been successfully applied in Indonesia will be described in detail in Section 4.3.

\subsection{Producing Improved Planting Stock for Post-Mining Reclamation}

The success of reforestation in post-mining land is determined by some factors, one of which is planting activities and the availability of planting stock [131]. The preparation of quality seedlings through plant propagation is important in post-mining land revegetation activities, especially with the use of local species, whose silvicultural techniques are usually little known [111]. For local species, generative propagation is generally chosen because it is provided in the mining area [132]. Meanwhile, vegetative propagation is used for the propagation of superior clones that are resistant to extreme post-mining land conditions [133] as well as trees with an irregular fruiting season or trees with constrained generative reproduction. The vegetative propagation of Melaleuca cajuputi has been practiced in the nurseries and produced a large number of planting stocks for reforestation [134]. Furthermore, the needs for planting native stocks for reclamation has been supported by the availability of propagation techniques for many native tropical trees, such as Taxus sumatrana, Styrax spp., and various species within the genus of Shorea, Hopea, Dipterocarpus, Drybalanops, Vatica, Parashorea, Upuna, Anisoptera, and Cotylelobium [135-141]. Thus, reforestation using native tree species becomes more feasible than it was several decades ago. 
The application of soil ameliorants, such as coal ash and humic substances, during the planting stock preparation in the nursery can also significantly increase the seedling performance and growth of Jabon trees [142]. A successful nursery management produced high-quality seedlings for reforestation on post-coal-mining areas in South Kalimantan, and it was reported that the survival rate of planting stocks in the field reached more than $80 \%[122,143]$. Some species also required certain techniques to improve their performance with the addition of mycorrhizae and the use of microbial inoculants in the nursery [144]. Twenty tree species were associated with Arbuscular Mycorrhizal Fungi (AMF) in postnickel mining lands in South Sulawesi [145]. The AMF association also found that there were 16 pioneer species spontaneously invading nickel post-mining land in South East Sulawesi, which included grasses, herbs, shrubs, and trees with an AMF colonization level of $0.83-50 \%$ [146]. Colonization of native Arbuscular Mycorrhizae (AM) fungi in the root system of various shrubs species has been recorded and shown in Figure 8.

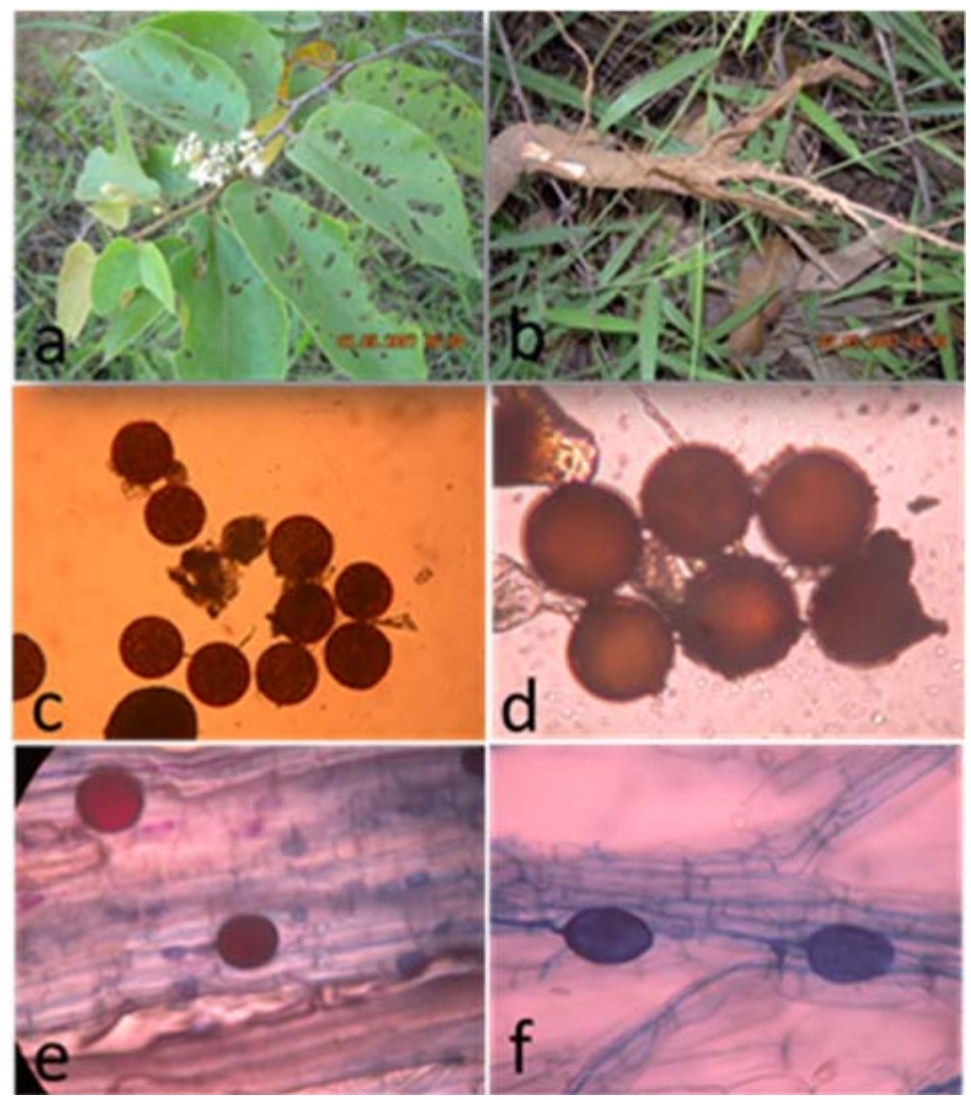

Figure 8. Native arbuscular mycorrhizal (AM) fungi colonized the shrub roots of Commersonia bartramia (Sterculiaceae) in degraded post-coal-mining lands in South Kalimantan, Indonesia; (a,b) shoot and roots of C. bartramia; (c,d) spore of native AM fungi associated in the rhizosphere of shrub growing in post-mining lands; (e,f) arbuscules and vesicles found in root systems of $C$. bartramia.

Symbiotic soil microbes play an important role in determining the performance of planted seedlings. The lack of population and diversity of symbiotic soil microbes in mining land will retard the natural succession process, thus hampering the success of restoring post-mining land. The AMF genera found in the East Kalimantan post-mining areas were Acaulospora and Glomus [147], while in South Sumatra, post-coal-mining areas were Glomus, Gigaspora, and Acaulospora [148]. A scant AMF population was also found in the coal post-mining areas in Muaro Jambi. The AMF spore density in the areas was less than four spores per $100 \mathrm{~g}$ of soil samples [127]. A parallel condition was also found in the nickel post-mining areas in South Sulawesi and Southeast Sulawesi. The types of mycorrhizal fungi found in both locations were Acaulospora and Glomus, with a very low spore density with less than 80 spores per $100 \mathrm{~g}$ of soil samples [146,149]. 
The impact of the application of symbiotic soil microbes proved to improve the quality of seedlings and plant growth in coal post-mining lands in Indonesia. AMF improved the early growth of trees in post-coal-mining areas [150,151]. Sesbania grandiflora inoculated with AMF in Central Kalimantan coal post-mining areas had a significant impact on control plants four months after transplanting (Figure 9) [150]. The inoculation of symbiotic soil microbe isolates had a positive effect on the plant growth in mineral post-mining areas [152-159].

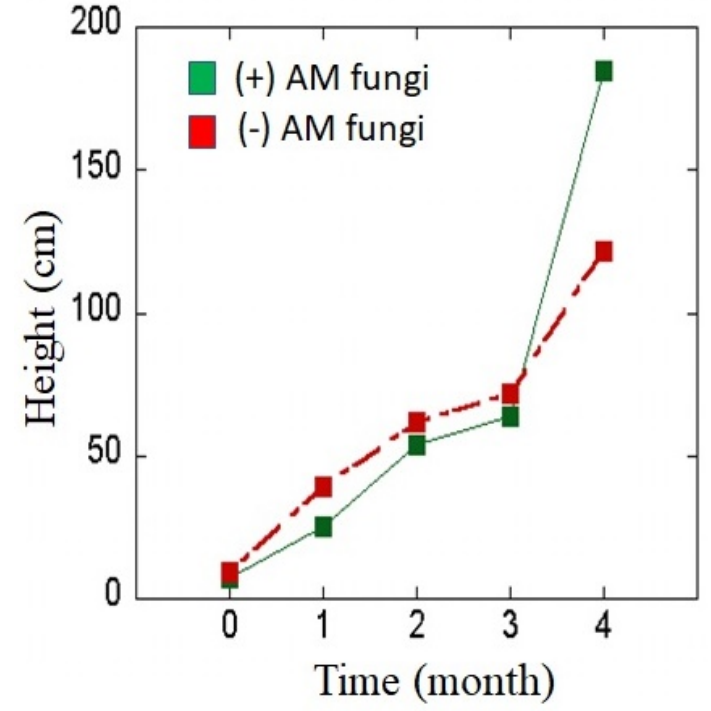

(a)

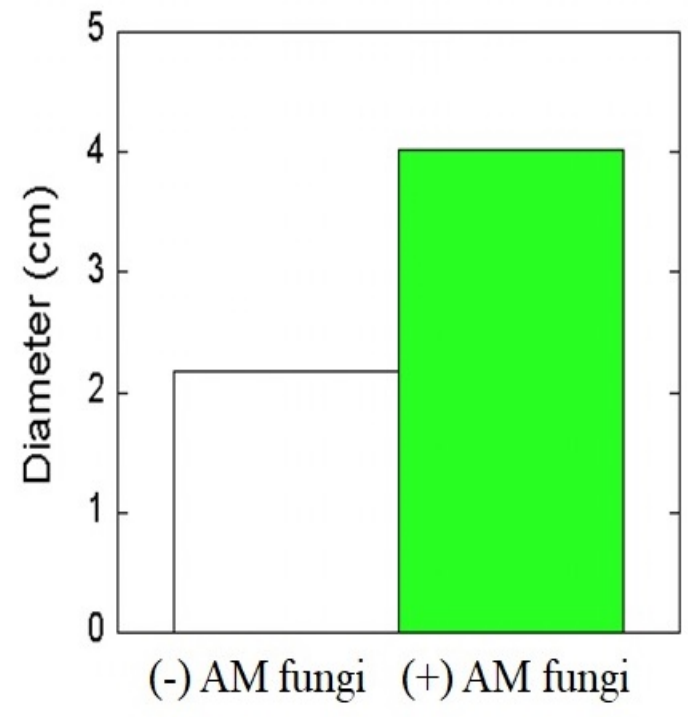

(b)

Figure 9. Reforesting post-coal-mining using Sesbania grandiflora inoculated with Arbuscular Mycorrhizal (AM) fungi and without AM fungi: (a) shoot height 1 to 4 months after transplanting, (b) diameter 4 months after transplanting [150]; (the histogram has been modified).

The AMF in the mine soil at the Binungan site, Berau, with a 10 -year-old reforestation amounted to 492 spores per $20 \mathrm{~g}$ soils, while in the areas that were not reforested, the number was only 12 spores per $20 \mathrm{~g}$ soils. This showed that AMF populations had a positive correlation with the level of soil organic matter [147]. AMF application and fastgrowing legume species of Pongamia pinnata increased both nutrient contents of post-coal mine soil and iron absorption, which was mostly accumulated in the root system [41]. AMF Gigaspora margarita and E. cyclocarpum seedlings could tolerate Hg metal supply [160]. Colonization by AMF inoculant improved plant resistance to acidity and phytotoxic levels of aluminum in the soil ecosystem [161]. AMF inoculation could decline the toxic reaction of As on Gmelina arborea in disturbed soil under the nursery conditions [162] on corn (Zea mays) growth in lead-contaminated soil [163]. The result showed the potential of AMF utilization and carbonized rice hull (CRH) to enhance the growth of Paraserianthes falcataria under the $\mathrm{Cu}$-stressed soil [164]. Improvements in the physico-chemical properties of mine soil with an increasing revegetation plant age also occurred in the parameters of organic $C$, total $\mathrm{N}$, and available $\mathrm{P}$, with a decrease in soil bulk density [132,165-167]. Utilization of mycorrhizal fungi and Rhizobia as symbiotic nitrogen-fixing bacteria by single, double, or consortium inoculation or combined with organic fertilizer to improve plant growth in coal and mineral post-mining lands in Indonesia was reported and displayed in Table 1. 
Table 1. Application of mycorrhizal fungi, Rhizobium sp., and organic fertilizer in post-coal and mineral mining lands in Indonesia.

\begin{tabular}{|c|c|c|c|c|}
\hline $\begin{array}{l}\text { Coal and Mineral } \\
\text { Mining Land }\end{array}$ & Plant Species & Treatments & Experiment Sites & Sources \\
\hline \multirow[t]{4}{*}{$\begin{array}{l}\text { Coal (East Kalimantan } \\
\text { Province) }\end{array}$} & $\begin{array}{c}\text { Albizia saman } \\
\text { Paraserianthes falcataria }\end{array}$ & $\begin{array}{c}\text { Glomus clarum/Rhizophagus } \\
\text { clarus } \\
\text { Gigaspora decipiens } \\
\text { Scutellespora sp. }\end{array}$ & Nursery and field & {$[151]$} \\
\hline & Pongamia pinnata & G. clarum & Nursery & {$[41]$} \\
\hline & Arachis hypogea & Rhizobium sp. + compost & Nursery & {$[168]$} \\
\hline & Glycine max. L. & AMF + liquid organic fertilizer & Nursery & [169] \\
\hline $\begin{array}{l}\text { Coal (South Kalimantan } \\
\text { Province) }\end{array}$ & $\begin{array}{l}\text { Sesbania granfolia } \\
\text { P. falcataria }\end{array}$ & G. clarum + compost + manure & Nursery and field & {$[150]$} \\
\hline \multirow[t]{3}{*}{ Coal (Jambi Province) } & Elaeis guineensis & Glomus spp. & Nursery & {$[170]$} \\
\hline & $\begin{array}{l}\text { soybean, corn, setaria and } \\
\text { cover crops }\end{array}$ & $\mathrm{AMF}+$ Manure & Nursery & {$[127]$} \\
\hline & G. $\max \mathrm{L}$. & $\begin{array}{l}\text { Glomus spp., Acaulospora, } \\
\text { Scutellospora spp. }\end{array}$ & Nursery & {$[171]$} \\
\hline $\begin{array}{l}\text { Bauxite (Riau Archipelago } \\
\text { Province, Sumatera) }\end{array}$ & $\begin{array}{c}\text { Gmelina arborea } \\
\text { Samanea saman } \\
\text { Falcataria moluccana } \\
\text { Enterelobium cyclocarpum }\end{array}$ & $\begin{array}{l}\text { G. clarum/Rhizophagus clarus } \\
\text { G. decipiens }\end{array}$ & Nursery and field & {$[151]$} \\
\hline Tin (Bangka, Sumatera) & Reutealis trispermum & $\begin{array}{c}\text { AMF + Rhizobium sp. + } \\
\text { Phosphate solubilizing bacteria }+ \\
\text { soil amendments (volcanic ash, } \\
\text { biogas) }\end{array}$ & Nursery & {$[172]$} \\
\hline Tin (Bangka, Sumatera) & G. $\max \mathrm{L}$. & $\begin{array}{c}\text { Rhizobium sp. + organic } \\
\text { fertilizer (compost, husk, empty } \\
\text { palm fruit bunch) }\end{array}$ & Nursery & {$[173]$} \\
\hline Gold (West Java) & Samanea saman & $\begin{array}{c}\text { G. manihotis } \\
\text { Rhizobium sp. }\end{array}$ & Nursery and field & {$[153]$} \\
\hline Gold (Southeast Sulawesi) & Nauclea orientalis & $\begin{array}{c}\text { Glomus spp., Glomus aggeratum, } \\
\text { Acaulospora delicate }\end{array}$ & Nursery & {$[156]$} \\
\hline Gold (West Java) & Pericopsis mooniana & $\begin{array}{c}\text { Glomus aggregate + Rhizobium } \\
\text { sp. + Vermicompost }\end{array}$ & Nursery & {$[174]$} \\
\hline Nickel (South Sulawesi) & Canavalia ensiformis & Acaulospora sp. & Nursery & {$[155]$} \\
\hline $\begin{array}{l}\text { Nickle (Southeast } \\
\text { Sulawesi) }\end{array}$ & F. moluccana & Rhizobium sp. & Nursery & {$[158]$} \\
\hline Silica sand (West Java) & Ochroma bicolor & $\begin{array}{l}\text { Glomus mosseae } \\
\text { Gigaspora margarita } \\
\text { Acaulospora sp. } \\
\text { Rhizobium } \mathrm{sp} \text {. } \\
\text { Lime + Compost }\end{array}$ & Nursery & {$[154]$} \\
\hline Limestone (West Java) & Leucaena leucocephala & $\begin{array}{c}\text { G. mosseae } \\
\text { Gi. margarita } \\
\text { Acaulospora sp. } \\
\text { Scutellespora } \mathrm{sp} \text {. }\end{array}$ & Nursery & {$[157]$} \\
\hline $\begin{array}{l}\text { Limestone (South } \\
\text { Sulawesi) }\end{array}$ & Vitex cofassus & $\begin{array}{l}\text { Gigaspora sp. } \\
\text { Acaulospora sp. } \\
\text { Glomus sp. }\end{array}$ & Nursery and field & [159] \\
\hline
\end{tabular}

\subsection{Plantation and Management}

Revegetation of post-coal-mining areas in East Kalimantan generally follows three steps. It started with the planting of legume cover crops together with pioneer species or fast-growing species. The LCC were Centrosoma pubescens and Calopogonium sp. of $37 \mathrm{~kg} \mathrm{ha}^{-1}$ [143] or a mixture of C. pubescens, Calopogonium mucoides, and Mucuna sp. of $200 \mathrm{~kg} \mathrm{ha}^{-1}$ [96]. The fast-growing species were planted with the spacing of $3 \times 3 \mathrm{~m}$ [122], $4 \times 4 \mathrm{~m}[96,143]$, or $5 \times 5 \mathrm{~m}$ [175] to provide growing space for semi- 
tolerant species or climax species, which would be planted 2-3 years or 4 years after fast-growing species planting. The stand of two or three years $[127,143,176]$ or four years of the pioneer species [177] is able to create microclimates and provide favorable shading for the semi-tolerant or climax species. The five-to-seven-year-old pioneer stand was able to provide $50-70 \%$ crown cover, which is favorable for the shadetolerant species to grow [143]. Semi-tolerant species were planted with the spacing of $5 \times 5 \mathrm{~m}[96,177]$ or $10 \times 10 \mathrm{~m}$ [96]. The planting holes for both fast-growing and semi-tolerant species in post-coal-mining areas in Indonesia were usually performed with sizes of $20 \times 20 \times 20 \mathrm{~cm}$ [151], $30 \times 30 \times 30 \mathrm{~cm}$ [178,179], $30 \times 40 \times 40 \mathrm{~cm}$ [177],

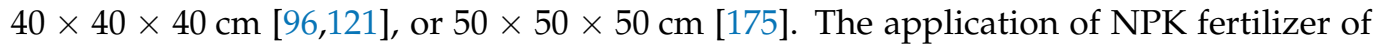
300-400 g per planting hole followed by compost application of 10-15 tons per hectares was a common practice in the reforestation of the post-mining areas in Kalimantan [96,122, 180,181].

Management was implemented after planting to ensure high seedling survival and good plant growth. Management activities applied in the post-mining forestation included re-planting, weeding, pruning, fertilizer application, and control of pests, disease, and fire $[96,143,175,177,182,183]$. Re-planting was performed to replace the mortal seedlings within one to two months after planting [175]. Weeding was conducted once every four months up to 1 year after planting and then once every six months in the second and the third year after planting $[143,184]$. Weeding was conducted to release the plants from the growing competition with the weeds. The growing competition could be in terms of the spacing or the nutrient absorption [122,176]. The common weeds in post-coalmining areas were usually in the form of grasses and climbing species such as Mikania sp. [121,127]. Other weed species present in the areas were Asystasia gangetica, Melastoma malabatrichum, Imperata cylindrica, and Paspalum conjugatum [127]. Weeding was conducted by removing the weeds at a distance of $1 \mathrm{~m}$ surrounding the main plant $[183,185]$. Those weeds were not thrown away but were placed surrounding the plants for mulching [122,179].

\subsection{Evaluation of Reclamation Process}

Every mining permit holder is obliged to perform reclamation following the mining stages that have been implemented [185]. The reclamation aimed to reduce the impact of open-pit mining, and its success was largely determined by the process of improving soil quality [59]. Progress in implementing the reclamation was monitored and evaluated in stages to ensure that the reclamation follows the approved annual and five-year plans. The monitoring was executed in stages every three months within 5 years of reclamation planning to monitor the progress of reclamation work. The final evaluation was conducted to determine the success rate of reclamation before the reclaimed area was returned to the government [186,187].

In monitoring and evaluation, the success of reclamation implementation was often seen only in terms of the post-mining areas that had been revegetated [127]. However, according to the ministerial regulations, monitoring should also be performed in stages following the progress of land management implementation, control of erosion and sedimentation, and the progress of the revegetation itself. Each of these components has an equally important weight in the monitoring process, and their implementation must follow the principle of measurable, reportable, and verifiable (MRV).

Monitoring the progress of the reclamation activities often receives less attention due to a number of obstacles. In East Kalimantan, where the number of coal mines reached 400 units, there were only 58 mine inspectors who had to conduct supervision every three months. Coupled with the lack of operational costs, monitoring activities still depended on assistance from the mining companies $[10,185]$. This condition could be improved by utilizing a remote sensing technology verified by a ground-based inventory [187-189]. In an area that is still affordable, the use of drones is the right choice to reduce monitoring time and costs [176]. Monitoring itself does not cover only the outputs resulting from the 
reclamation activities such as the growth of vegetation or the soil conservation facilities; it is also performed to discover the outcome or the impact of the resulting output, such as the decreasing erosion and sedimentation, water system improvement, or higher biodiversity index $[129,190]$. Likewise, the benefits generated from reclamation activities must also be included in the monitoring item.

In the MoEMR Regulation, the weight of the reclamation activity assessment includes $60 \%$ for land management, $20 \%$ for revegetation, and $20 \%$ for completion. Land management has the greatest weight contributed by the arrangement of the land surface and the stockpiling of post-mining areas $(40 \%)$, spreading soil in the root zone $(10 \%)$, and controlling erosion and surface runoff $(10 \%)$. Revegetation activities only receive a small weight, which includes the planting of cover crop $(2.5 \%)$, fast-growing plants $(7.5 \%)$, local plant species (5\%), and controlling acid mine drainage (5\%). In completion, the success of reclamation is determined by plant canopy cover $(10 \%)$ and maintenance activities $(10 \%)$.

The reclamation assessment of post-mining in the forest areas is regulated by the Ministry of Environment and Forestry. Apart from revegetation that has the highest weight $(50 \%)$, the assessment also includes land management and sediment and erosion control, rated with a weight of $30 \%$ and $20 \%$ respectively. Revegetation is assessed based on several criteria, namely the percentage of revegetation area compared to the target with the lowest score if it is less than $60 \%$, survival rate with the lowest score if it reaches less than $60 \%$, tree density with an assessment range from less than 400 trees ha $^{-1}$ up to more than 625 trees ha $^{-1}$, the composition of local tree species with the lowest score if the percentage is less than $10 \%$, and plant health with the lowest score if the percentage of healthy plants is less than $60 \%$. For the land management aspect, the elements that are assessed include the activities of backfilling in ex-mine pits, sowing topsoil, and land stability in the designated area. Sediment and erosion control activities include soil conservation facilities, cover crops, and erosion and sedimentation values.

Mining reclamation techniques have seen a dramatic improvement in recent years due to creative new methods and technologies that are pushing the process beyond simple restoration. Open-pit mines are now being used for research, public parks, forests, and even farmlands. With the proper tools and planning, mining can boost the economy, provide us with the necessary resources, and remain environmentally friendly. Several reclamation areas of post-coal-mining in East Kalimantan, Indonesia, have been used as a multifunctional conservation area, including for educational benefit, research destination, species collection/conservation, and a source of non-timber forest products (e.g., stingless honey bees, medicinal plants, leaf fiber from Curculigo latifolia as a beautiful traditional woven cloth, and food sources) [120,191-193].

The pit lakes formed from the mining pit in East Kalimantan were well utilized as a source of drinking water in one of the coal mining companies. The water quality in the Jupiter pit void, for instance, which was regularly monitored, showed first-class water quality. Analysis of water availability was also conducted, and the pit void was able to produce $260 \mathrm{~L} \mathrm{~second}^{-1}$ for the company's internal needs and the regional drinking water company of East Kutai [194]. Another void located in Telaga Batu Arang [195] was used for recreational areas. The pit lake of Telaga Batu Arang (formerly name Sangatta North) has an average depth of about $31.68 \mathrm{~m}$. The direct measurement results of surface and bottom water $\mathrm{pH}$ in this lake were $7.64 \pm 0.12$ and $6.21 \pm 0.18$. The differences in the $\mathrm{pH}$ value of water on the surface and the bottom of the lake, which was smaller than 1.4, were caused by the characteristics of the pit lake sediment. The sediment had Ca levels of 1.205-1.872 and $\mathrm{Mg}$ 16.4-19.6 $\mathrm{mg} \mathrm{kg}^{-1}$ [196]. Another example was Lake Seran, a pit lake from a former diamond mine in South Kalimantan. This pit lake became a new tourism and sightseeing area near Banjarmasin, the capital of South Kalimantan, probably due to the lack of tourism areas for residents. This pit lake is about $30 \mathrm{~m}$ deep and has a very acidic $\mathrm{pH}$, around 3.75, which is certainly not suitable for long-term daily use [197]. This shows that more in-depth and serious attention is needed to study the characteristics of pit 
lakes in Indonesia to facilitate the planning of the final use of these pit lakes in terms of their respective characteristics.

Planting multi-species at post-coal-mining lands accelerates the succession stage, increases plant biodiversity [129], and serves as a food source for various wild animals that support the diversity of the fauna [198]. The biodiversity of wildlife can be used as a bio-indicator to assess the success of post-coal-mining reclamation activities $[199,200]$. The presence and the diversity of wildlife species in post-coal-mining reclamation areas are closely related to the potential of vegetation diversity as food sources [24,200,201]. The more diverse vegetation species provide more diverse wildlife [201,202]. Selecting proper tree species in many sites of post-coal-mining areas in East Kalimantan created a supported environment for various wild animals including Nasalis larvatus (Figure 10), Pongo pygmaeus (Figure 11), Helarctos malayanus, Prionailurus bengalensis, Tragulus napu, Muntiacus muntjak, Neofelis diardi borneensis, and others [191-193,199,201,203].

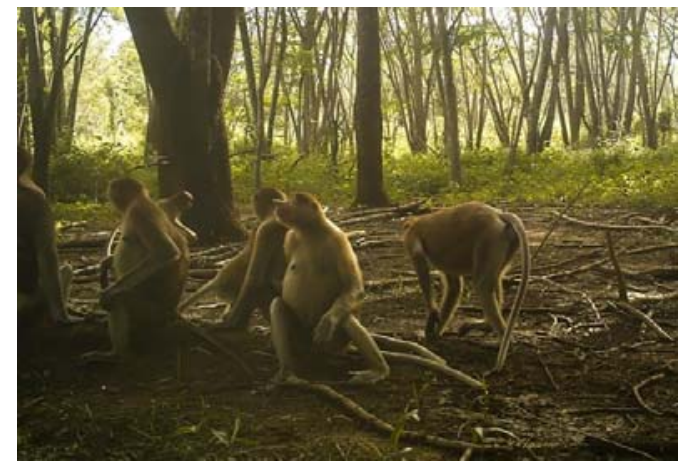

(a)

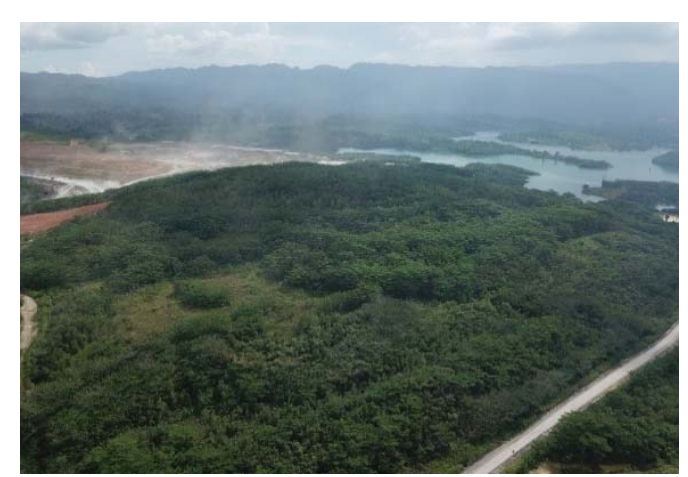

(b)

Figure 10. (a) Bekantan (Nasalis larvatus) in (b) rehabilitated post-coal-mining sites that was later converted into an arboretum in Penajam Paser Utara, East Kalimantan, Indonesia; Photo by Yaya Rayadin.

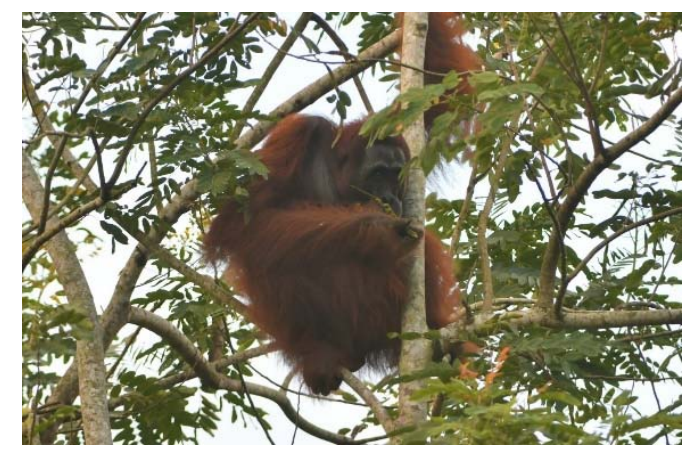

Figure 11. Adult male orangutan (Pongo pygmaeus) in reclamation post-coal-mining forest, eating the flowers and fruit of Johar (Casia siamea). Photo by Yaya Rayadin.

Various experiences and best practices in the implementation of post-mining reclamation show that degraded ex-mining land is not impossible to make productive again. Land management and reforestation of the post-mining land, if carried out following the provisions, will contribute to an increase in the area of tropical forests, which in turn can improve environmental conditions and have the potential to increase community income. The success of post-mining reclamation in restoring tropical forest cover can also support the conservation of biodiversity through the provision of animal habitats that lead to or approach their natural conditions.

\section{Conclusions}

Coal mining is one of the biggest drivers of the Indonesian economy and national development. Management of the mining areas is not only about extracting mining 
resources, but also about ensuring the sustainability of the post-mining areas to function well ecologically. As mining has diverse environmental changeability, it requires proper complete planning from the initial to the post-mining stages. In this regard, the government has issued various rules and laws regulating its management aspects ranging from planning to post-mining land reclamation. An effort to make the post-mining areas a more productive ecosystem is stipulated in various government regulations that must be fulfilled by every mining permit holder. This has been supported by the availability of technology that supports the implementation of reclamation starting from rearranging the overburden and soil materials, controlling acid mine drainage and erosion and management of the drainage system, and settling ponds and pit lakes. Many efforts to reclaim post-coalmining lands and their success rate have been reported and highlighted. Several reviews of the successful implementation of ex-coal-mine reclamation have been able to restore forest functions in providing forests with values for their ecological, economic, and social function (i.e watershed protection, maintain biodiversity, wildlife habitat, local livelihood, and other environmental services). The successful approach may include several steps such as creating a suitable rooting medium, preparing more habitable condition by planting cover crops that can keep a balance function of controlling erosion and competition level for the light, water, and space required by trees, planting fast-growing pioneer trees and other native late-stage species, using proper tree planting technique, and monitoring the growth and success of the planting activities. Post-coal mining areas whose landscape cannot be returned through reclamation efforts, known as pit lakes, should be managed to have a more intensive portion so that they still have a high ecological biodiversity value and are more economically beneficial.

Author Contributions: Each author (P., B.H.N., C.A.S., M.T., A.H., H.H.R., B.M., S., I., R.M., Y.R., R.P. (Retno Prayudyaningsih), T.W.Y., R.P. (Ricksy Prematuri) and A.S.) has an equal role as the main contributor who equally discussed the conceptual ideas and the outline, provided critical feedback for each section, and helped shape and write the manuscript. All authors have read and agreed to the published version of the manuscript.

Funding: This research received no external funding.

Institutional Review Board Statement: Not applicable.

Informed Consent Statement: Not applicable.

Data Availability Statement: Not applicable.

Acknowledgments: We thank anonymous reviewers.

Conflicts of Interest: The authors declare no conflict of interest.

\section{References}

1. Adriani, E.; Gustaman, S.; Saputri, D.R.; Kusnadi, E.; Suheri; Emo, M. Export Commodity Analysis, 2012-2019, Agriculture, Industry and Mining Sector; Statistics Indonesia: Jakarta, Indonesia, 2020.

2. Ministry of Energy and Mineral Resources. Handbook of Energy \& Economic Statistics of Indonesia; Ministry of Energy and Mineral Resources: Jakarta, Indonesia, 2020.

3. Hilmawan, R.; Yudaruddin, R.; Wahyuni, Y.S. Coal mining operations and its impact on sectoral and regional area: Evidence of East Kalimantan, Indonesia. J. Indones. Appl. Econ. 2016, 6, 22-42. [CrossRef]

4. Devi, B.; Prayogo, D. Mining and Development in Indonesia: An Overview of the Regulatory Framework and Policies; International Mining for Development Centre: Queensland, Australia, 2013.

5. Kramadibrata, S. Review of the mineral development in Indonesia. Procedia Earth Planet. Sci. 2013, 6, 6-7. [CrossRef]

6. Prematuri, R.; Turjaman, M.; Sato, T.; Tawaraya, K. The impact of nickel mining on soil properties and growth of two fast-growing tropical tree species. Int. J. For. Res. 2020, 1-9. [CrossRef]

7. Alexiades, M.N.; Shanley, P. Forest Products, Livelihoods and Conservation: Case Studies of Non-Timber Forest Product Systems. Volume 3-Latin America; Center for International Forestry Research: Bogor, Indonesia, 2004.

8. Segura-Salazar, J.; Tavares, L.M. Sustainability in the mineral industry: Seeking a Concensus on its meaning. Sustainability 2018, 10, 1429. [CrossRef]

9. Statistical Review of World Energy 2020, 69th ed. Available online: https:/ / bp.com/statisticalreview (accessed on 8 June 2021). 
10. Kristanti, R.; Kartodihardjo, H.; Nugroho, B.; Mansur, I. Institutional performance of mining reclamation in forest areas of East Kalimantan. J. Manaj. Hutan Trop. 2019, 25, 69-81. [CrossRef]

11. Kodir, A.; Hartono, D.M.; Haeruman, H.; Mansur, I. Integrated post-mining landscape for sustainable land use: A case study in South Sumatera, Indonesia. Sustain. Environ. Res. 2017, 27, 203-213. [CrossRef]

12. Park, J.; Kwon, E.; Chung, E.; Kim, H.; Battogtokh, B.; Woo, N.C. Environmental sustainability of open-pit coal mining practices at Baganuur, Mongolia. Sustainability 2020, 12, 248. [CrossRef]

13. Popović, V.; Miljković, J.Ž.; Subić, J.; Jean-Vasile, A.; Adrian, N.; Nicolãescu, E. Sustainable land management in mining area in Serbia and Romania. Sustainability 2015, 7, 11857-11877. [CrossRef]

14. Pietrzykowski, M. Tree species selection and reaction to mine soil reconstructed at reforested post-mine sites: Central and eastern European experiences. Ecol. Eng. X 2019, 3, 100012. [CrossRef]

15. Borišev, M.; Pajević, S.; Nikolić, N.; Pilipović, A.; Arsenov, D.; Župunski, M. Mine site restoration using silvicultural approach. In Bio-Geotechnologies for Mine Rehabilitation; Prasard, M.N.V., Favas, P.J.C., Maiti, S.K., Eds.; Elsevier: Amsterdam, The Netherlands, 2018; pp. 115-129.

16. Adams, B.E.; Angel, P.; Barton, C.; Burger, J.; Davis, V.; French, M.; Graves, D.; Groninger, J.W.; Hall, N.; Keiffer, C.H.; et al. The Forestry Reclamation Approach: Guide to Successful Reforestation of Mined Lands, United States Department of Agriculture; United States Department of Agriculture: Washington, DC, USA, 2017.

17. Macdonald, S.E.; Landhäusser, S.M.; Skousen, J.; Franklin, J.; Frouz, J.; Hall, S.; Jacobs, D.F.; Quideau, S. Forest restoration following surface mining disturbance: Challenges and solutions. New For. 2015, 46, 703-732. [CrossRef]

18. Jaringan Dokumentasi dan Informasi Hukum Kementerian Energi dan Sumber Daya Mineral. Available online: https://jdih. esdm.go.id (accessed on 8 June 2021).

19. Jung, D.; Choi, Y. Systematic review of machine learning applications in mining: Exploration, exploitation, and reclamation. Minerals 2021, 11, 148. [CrossRef]

20. Abaidoo, C.A.; Osei, E.M.; Arko-Adjei, A.; Prah, B.E.K. Monitoring the extent of reclamation of small scale mining areas using artificial neural networks. Heliyon 2019, 5, e01445. [CrossRef] [PubMed]

21. Feng, Y.; Wang, J.; Bai, Z.; Reading, L. Effects of surface coal mining and land reclamation on soil properties: A review. Earth Sci. Rev. 2019, 191, 12-25. [CrossRef]

22. Jaringan Dokumentasi dan Informasi Hukum Kementerian Lingkungan Hidup dan Kehutanan. Available online: https: / /jdih.menlhk.co.id (accessed on 8 June 2021).

23. Putra, H.F.; Sulistijorini; Aryanti, N.S. Landscape function of post tin-mining land after reclamation in Bangka, Indonesia. IOP Conf. Ser. Earth Environ. Sci. 2017, 58, 012018. [CrossRef]

24. Nugroho, A.W.; Yassir, I. Policy study on post coal mining reclamation assessment in Indonesia. J. Anal. Kebijak. Kehutan. 2017, 14, 121-136.

25. Oktorina, S. Ex-mining land reclamation and revegetation policy (case study of Indonesian coal mining). Al-Ard J. Tek. Lingkung. 2017, 3, 16-20.

26. Yu, X.; Mu, C.; Zhang, D. Assessment of land reclamation benefits in mining areas using fuzzy comprehensive evaluation. Sustainability 2020, 12, 2015. [CrossRef]

27. Ignatyeva, M.; Yurak, V.; Pustokhina, N. Recultivation of post-mining disturbed land: Review of content and comparative law and feasibility study. Resources 2020, 9, 73. [CrossRef]

28. Hartono, B.; Imran, A.M.; Idrus, M.R. Strategic reclamation policy of post-mining area based in the enviroment in North Kolaka district. IOP Conf. Ser. Earth Environ. Sci. 2020, 575, 012248. [CrossRef]

29. MoEF (Ministry of Environment and Forestry). Information System of Leasehold License of the Forest Area. Available online: http:/ / ppkh.menlhk.go.id (accessed on 1 April 2021).

30. Kristanti, R.; Kartodihardjo, H.; Nugroho, B.; Mansur, I. Effects of the transfer of rights and jurisdictions on mining reclamation performance in state forest areas in East Kalimantan. J. Manaj. Hutan Trop. 2020, 26, 133-143. [CrossRef]

31. Mansur, I. Integrating biodiversity conservation and agricultural production in mine reclamation for sustainable development. $J$. Dev. Sustain. Agric. 2012, 7, 97-102.

32. Liu, R.; Lal, R. Quality change of mine soils from different sources in response to amendments-A Laboratory study. Environ. Nat. Resour. Res. 2014, 4, 20-38. [CrossRef]

33. Mushia, N.M.; Ramoelo, A.; Ayisi, K.K. The impact of the quality of coal mine stockpile soils on sustainable vegetation growth and productivity. Sustainability 2016, 8, 546. [CrossRef]

34. Ghose, M.K. Effect of opencast mining on soil fertility. J. Sci. Ind. Res. 2004, 63, 1006-1009.

35. Skousen, J.G.; Sexstone, A.; Ziemkiewicz, P.F. Acid mine drainage control and treatment. In Reclamation of Drastically Disturbed Lands American Society of Agronomy and American Society for Surface Mining and Reclamation; Agronomy No. 41; Barnhisel, R.I., Darmody, R.G., Daniels, W.L., Eds.; American Society of Agronomy: Madison, WI, USA, 2000.

36. Trumm, D. Selection of active and passive treatment systems for AMD—Flow charts for New Zealand conditions. N. Z. J. Geol. Geophys. 2010, 53, 195-210. [CrossRef]

37. Pozo-Antonio, S.; Puente-Luna, I.; Lagüela-López, S.; Veiga-Ríos, M. Techniques to correct and prevent acid mine drainage: A review. DYNA 2014, 81, 73-80. [CrossRef] 
38. Skousen, J.G.; Ziemkiewicz, P.F.; McDonald, L.M. Acid mine drainage formation, control and treatment: Approaches and strategies. Extr. Ind. Soc. 2018, 6. [CrossRef]

39. Sharma, S.; Lee, M.; Reinmann, C.S.; Pumneo, J.; Cutright, T.J.; Senko, J.M. Impact of acid mine drainage chemistry and microbiology on the development of efficient Fe removal activities. Chemosphere 2020, 249, 126117. [CrossRef]

40. RoyChowdhury, A.; Sarkar, D.; Datta, R. Remediation of acid mine drainage-impacted water. Curr. Pollut. Rep. 2015, 1, 131-141. [CrossRef]

41. Agus, C.; Primananda, E.; Faridah, E.; Wulandari, D.; Lestari, T. Role of arbuscular mycorrhizal fungi and Pongamia pinnata for revegetation of tropical open-pit coal mining soils. Int. J. Environ. Sci. Technol. 2019, 16, 3365-3374. [CrossRef]

42. Setiawan, A.A.; Budianta, D.; Suheryanto; Priadi, D.P. Review: Pollution due to coal mining activity and its impact on environment. Sriwij. J. Environ. 2018, 3, 1-5. [CrossRef]

43. Gautama, R.S.; Kusuma, G.J.; Abfertiawan, M.S.; Wiedhartono, A.; Gunawan, F.; Lestari, I.; Simbolon, R.; Diana, M.R. Study on capping options for overburden encapsulation to prevent acid mine drainage in Lati coal mine, East Kalimantan, Indonesia. In Proceedings of the Annual International Mine Water Association Conference-Reliable Mine Water Technology, Golden, CO, USA, 6-9 August 2013.

44. Abfertiawan, M.S.; Palinggi, Y.; Handajani, M.; Pranoto, K.; Atmaja, A. Evaluation of non-acid-forming material layering for the prevention of acid mine drainage of pyrite and jarosite. Heliyon 2020, 6, 1-8. [CrossRef]

45. Kusuma, G.J.; Shimada, H.; Sasaoka, T.; Matsui, K.; Nugraha, C.; Gautama, R.S.; Sulistianto, B. An evaluation on the physical and chemical composition of coal combustion ash and its co-placement with coal-mine waste rock. J. Environ. Prot. 2012, 3, 589-596. [CrossRef]

46. Kusuma, G.J.; Shimada, H.; Nugraha, C.; Hamanaka, A.; Sasaoka, T.; Matsui, K.; Gautama, R.S.; Sulistianto, B. Study on co-placement of coal combustion ash-coal waste rock for minimizing acid mine drainage generation: A preliminary result of field column test experiment. Procedia Earth Planet. Sci. 2013, 6, 251-261. [CrossRef]

47. Iskandar, S.; Gautama, R.S. Acid mine drainage management in Indonesian mines. In Proceedings of the 7th Australian Workshop on AMD, Darwin, Australia, 21-24 June 2011.

48. Matsumoto, S.; Ishimatsu, H.; Shimada, H.; Sasaoka, T.; Kusuma, G.J.; Gautama, R.S. Placement of waste rocks in waste dump for prevention of Acid Mine Drainage (AMD) by cover system in open cast coal mine: Effects of water quality on AMD. Inz. Miner. 2017, 1, 97-102.

49. Prihatini, N.S.; Priatmadi, B.J.; Masrevaniah, A.; Soemarno. Performance of the horizontal subsurface-flow constructed wetlands with different operational procedures. Int. J. Adv. Eng. Technol. 2015, 7, 1620-1629.

50. Prihatini, N.S.; Nirtha, I.; Iman, M.S. Role of purun tikus in vertical subsurface flow constructed wetland in treating manganese (Mn) from coal mine drainage. Trop. Wetl. J. 2016, 2, 1-7. [CrossRef]

51. Munawar, A.; Leitu, F.O.; Bustamam, H. Aquatic plants for acid mine drainage remediation in simulated wetland systems. J. Nat. Indones. 2011, 13, 244-249. [CrossRef]

52. Sekarjannah, F.A.; Wardoyo, S.S.; Ratih, Y.W. Management of mine acid drainage in a constructed wetland using hyacinth plants and addition of organic materials. J. Degrad. Min. Lands Manag. 2019, 6, 1847-1855. [CrossRef]

53. Zipper, C.E.; Burger, J.A.; Barton, C.D.; Skousen, J.G. Rebuilding soils on mined land for native forests in Appalachia. Soil Sci. Soc. Am. J. 2013, 77, 337-349. [CrossRef]

54. Novianti, V.; Choesin, D.N.; Iskandar, D.T.; Suprayogo, D. Plant species from coal mine overburden dumping site in Satui, South Kalimantan, Indonesia. J. Degrad. Min. Lands Manag. 2017, 4, 927-936. [CrossRef]

55. Daniels, W.L.; Haering, K.C.; Galbraith, J.M. Mine Soil Morphology and Properties in Pre- and Post-SMCRA Coal Mined Landscapes in Southwest Virginia. In Proceedings of the 2004 National Meeting of the America Society of Mining and Reclamation, Lexington, KY, USA, 18-24 April 2004; p. 421. [CrossRef]

56. Sheoran, V.; Sheoran, A.S.; Poonia, P. Soil reclamation of abandoned mine land by revegetation: A review. Int. J. Soil Sediment Water 2010, 3, 1-20.

57. Zulkarnain, Z.; Joy, B.; Tuhpawana, P.; Prawira, I. Soil erosion assessment of the post-coal mining site in Kutai Kartanagera District, East Kalimantan Province. Int. J. Sci. Eng. 2014, 7, 130-136. [CrossRef]

58. Tambunan, R.P.; Syekhfani, S.; Priatmadi, B.J. The role of ground cover plant in soil improvement after mining activity in South Kalimantan. IOSR J. Agric. Vet. Sci. 2017, 10, 92-98.

59. Noviyanto, A.; Purwanto; Minardi, S.; Supriyadi. The assessment of soil quality of various age of land reclamation after coal mining: A chronosequence study. J. Degrad. Min. Lands Manag. 2017, 5, 1009-1018. [CrossRef]

60. Sopialena, S.; Rosfiansyah, R.; Sila, S. The benefit of topsoil and fertilizer mixture to improve the ex-coal mining land. Nusant. Biosci. 2017, 1, 36-43. [CrossRef]

61. Sobek, A.A.; Skousen, J.G.; Fisher, A.E. Chemical and physical properties of overburdens and minesoils. In Reclamation of Drastically Disturbed Lands; Barnhisel, R.I., Darmody, R.G., Daniels, W.L., Eds.; Agronomy Monograph No. 41; American Society of Agronomy: Madison, WI, USA, 2000.

62. Suryaningtyas, D.T.; Sulistijo, B.; Iskandar, I.; Sudadi, U.; Kusumo, A.D.; Srihartati, Y. Handbook for Best Available Practice in Onshore Alluvial Tin Mine Reclamation in Indonesia: Lessons Learned from the Air Kundur 3 Pilot Project, Bangka-Belitung Province; Bundesanstallt für Geowissenschaften und Rohstoffe: Hanover, Germany, 2019. 
63. Inonu, I.; Kusmiadi, R.; Yuliana, A.; Nurtjahya, E. The amelioration of post tin mining sand tailing medium with chicken manure for pepper cultivation. J. Suboptimal Lands 2020, 9, 31-40. [CrossRef]

64. Narendra, B.H.; Mulyanto, B. Soil properties improvement and use of adaptive plants for land rehabilitation of post tin mining closure in Bangka Island, Indonesia. Biodiversitas 2020, 21, 505-511. [CrossRef]

65. Iskandar, I.; Suryaningtyas, D.T.; Baskoro, D.P.T.; Budi, S.W.; Gozali, I.; Maswahenu, M. A chronosequence study of soil properties and microclimate in the reclamation area of Batu Hijau Mine, West Sumbawa. IOP Conf. Ser. Earth Environ. Sci. 2019, 393, 012094. [CrossRef]

66. Procházka, J.; Brom, J.; Št'astny, J.; Pecharová, E. The impact of vegetation cover on the temperature and humidity properties in the reclaimed area of a brown coal dump. Int. J. Min. Reclam. Environ. 2011, 25, 350-366. [CrossRef]

67. Zhao, Y.; Li, X.; Zhang, P.; Hu, Y.; Huang, L. Effects of vegetation reclamation on temperature and humidity properties of a dumpsite: A case study in the open pit coal mine of Heidaigou. Arid Land Res. Manag. 2015, 29, 375-381. [CrossRef]

68. Inoue, N.; Hamanaka, A.; Shimada, H.; Sasaoka, T.; Matsui, K. Fundamental study on assessment of soil erosion by the USLE method at rehabilitation area in Indonesian coal mine. Earth Sci. Res. 2015, 4. [CrossRef]

69. Ward, A.; Smith, A.; Caldwell, J. Surface erosion and sediment control at open-cast mines in southern Africa. In Challenges in African Hydrology and Water Resources, Proceedings of the Harare Symposium, July 1984; IAHS Publ. No. 144; International Association of Hydrological Sciences: Wallingford, UK, 1984.

70. Hamanaka, A.; Inoue, N.; Shimada, H.; Sasaoka, T.; Matsui, K.; Miyajima, I. Design of self-sustainable land surface against soil erosion at rehabilitation areas in open-cut mines in tropical regions. Int. J. Min. Reclam. Environ. 2015, 29, 305-315. [CrossRef]

71. Pusat Studi Reklamasi Tambang IPB. Pemantauan Potensi Erosi di Areal Revegetasi PT Berau Coal, Kabupaten Berau, Kalimantan Timur; Unpublished Report to PT Berau Coal: Berau, Indonesia, 2017. (In Indonesian)

72. Kathuria, D.V.; Nawrocki, M.A.; Becker, B.C. Effectiveness of surface mine sedimentation ponds. In Environmental Protection Technology Series; EPA-600/2-76-117; U.S. Environmental Protection Agency: Springfield, VA, USA, 1976.

73. Pratama, Y.I.; Syaifudin, F.; Pranoto, K. Open pit-mine water management in equatorial area. In Mine Water Solution, Proceedings of the Postponed 14th IMWA Congress, Christchurch, New Zealand, 9-13 November 2020; Pope, J., Ed.; The International Mine Water Association: Wendelstein, Germany, 2020; pp. 168-173.

74. Prabowo, H.; Amran, A.; Arbain, A. Decreasing level of heavy metals Fe and Mn use the wetland method at coal open mining PT Bukit Asam South Sumatra Province. IOP Conf. Ser. Earth Environ. Sci. 2019, 314, 12023. [CrossRef]

75. Bratby, J. Coagulation and Flocculation with an Emphasis on Water and Wastewater Treatment; Uplands Press Ltd.: Croydon, UK, 1980.

76. Nugeraha, N.; Sumiyati, S.; Samudro, G. Waste water treatment of coal mining activities using biocoagulants: Study of reducing TSS, total Fe and total Mn using Moringa seeds (Moringa oleifera). J. Presipitasi 2010, 7, 57-61.

77. Zhao, L.Y.L.; McCullough, C.D.; Lund, M.A. Mine Voids Management Strategy (I): Pit Lake Resources of the Collie Basin; Center for Ecosystem Management, Edith Cowan University: Joondalup, Australia, 2009.

78. Soni, A.K.; Mishra, B.; Singh, S. Pit lakes as an end use of mining: A review. J. Min. Environ. 2014, 5, 99-111.

79. McCullough, C.D.; Schultze, M.; Vandenberg, J. Realizing beneficial end uses from abandoned pit lakes. Minerals 2020, 10, 133. [CrossRef]

80. Mentis, M. Environmental rehabilitation of damaged land. For. Ecosyst. 2020, 7, 1-16. [CrossRef]

81. Pratiwi; Narendra, B.H.; Hartoyo, G.M.E.; Kalima, T.; Pradjadinata, S. Atlas Jenis-Jenis Pohon Andalan Setempat Untuk Rehabilitasi Hutan dan Lahan di Indonesia; Forda Press: Bogor, Indonesia, 2014; p. 81. (In Indonesian)

82. Filoso, S.; Bezerra, M.O.; Weiss, K.C.B.; Palmer, M.A. Impacts of forest restoration on water yield: A systematic review. PLoS ONE 2017, 12, 183-210. [CrossRef]

83. Pratiwi; Narendra, B.H.; Wardhani, M. Pemilihan jenis pohon untuk konservasi tanah dan air dalam rangka pemulihan fungsi daerah aliran sungai. In Bunga Rampai. Dukungan IPTEK Rehabilitasi Hutan dan Lahan Dalam Pemulihan Fungsi Daerah Aliran Sungai; Pratiwi, Narendra, B.H., Pamungkas, A.G., Eds.; IPB Press: Bogor, Indonesia, 2020; pp. 47-69. (In Indonesian)

84. Pancel, L. Species selection in tropical forestry. In Tropical Forestry Handbook; Pancel, L., Köhl, M., Eds.; Springer: Berlin/Heidelberg, Germany, 2015. [CrossRef]

85. Chechina, M.; Hamann, A. Choosing species for reforestation in diverse forest communities: Social preference versus ecological suitability. Ecosphere 2015, 6, 1-13. [CrossRef]

86. Delgado, J.A.; Mosquera, V.H.B.; Alwang, J.R.; Aveiga, A.V.; Ayala, Y.E.C.; Neer, D.; Monar, C.; López, L.O.E. Potential use of cover crops for soil and water conservation, nutrient management, and climate change adaptation across the tropics. Adv. Agron. 2021, 165, 175-247. [CrossRef]

87. Nevins, C.J.; Nakatsu, C.; Armstrong, S. Characterization of microbial community response to cover crop residue decomposition. Soil Biol. Biochem. 2018, 127, 39-49. [CrossRef]

88. Xiao, Y.; Li, L.; Zhang, F. Effect of root contact on interspecific competition and $\mathrm{N}$ transfer between wheat and fababean using direct and indirect $15 \mathrm{~N}$ techniques. Plant. Soil 2004, 262, 45-54. [CrossRef]

89. Narendra, B.H.; Pratiwi. Adaptability of some legume trees on quartz tailings of a former tin mining area in Bangka Island, Indonesia. J. Degrad. Min. Lands Manag. 2016, 4, 671-674. [CrossRef]

90. De Lima, C.L.R.; Ezequiel, C.C.M.; Luis, C.T.; Eloy, A.P.; Alvaro, P.S. Soil compressibility and least limiting water range of a constructed soil under cover crops after coal mining in Southern Brazil. Soil Till. Res. 2012, 124, 190-195. [CrossRef] 
91. Hamza, M.A.; Anderson, W.K. Soil compaction in cropping systems: A review of the nature, causes and possible solutions. Soil Till. Res. 2005, 82, 121-145. [CrossRef]

92. Reichert, J.M.; Suzuki, L.E.A.S.; Reinert, D.J.; Horn, R.; Hakansson, I. Reference bulk density and critical degree compactness for no-till crop production in subtropical highly weathered soils. Soil Till. Res. 2009, 102, 242-254. [CrossRef]

93. Crusciol, C.A.C.; Nascente, A.S.; Borghi, E.; Soratto, R.P.; Martins, P.O. Improving soil fertility and crop yield in a tropical region with palisadegrass cover crops. Agron. J. 2015, 107, 2271-2280. [CrossRef]

94. Six, J.; Frey, S.D.; Thiet, R.K.; Batten, K.M. Bacterial and fungal contributions to carbon sequestration in agroecosystems. Soil Sci. Soc. Am. J. 2006, 70, 555-569. [CrossRef]

95. Yassir, I. Bersinergi dengan alam dalam mereklamasi hutan bekas tambang batubara. In Prosiding Seminar Hasil-Hasil Penelitian "Reklamasi Lahan Pasca Tambang: Aspek Kebijakan, Konservasi dan Teknologi; Gunawan, W., Ishak, Y., Puspanti, A., Eds.; Balai Penelitian Teknologi Konservasi Sumberdaya Alam: Samboja, Indonesia, 2015; pp. 3-10.

96. Maharani, R.; Susilo, A.; Sugiharto, S.; Fernandes, A. Revegetasi lahan bekas tambang batubara. In Status Riset Reklamasi Bekas Tambang Batubara: Revegetasi Lahan Bekas Tambang Batubara; Pratiwi, Widyati, E., Boer, C., Eds.; Balai Penelitian dan Pengembangan Kehutanan: Samarinda, Indonesia, 2010; pp. 23-34.

97. Narendra, B.H.; Pratiwi. Cover crops growth on tin-mined overburden in Bangka Island. Indones. For. Rehabil. J. 2014, 2, 15-24.

98. Prayogo, C.; Ihsan, M. Utilization of LCC (Legume Cover Crop) and bokashi for the efficiency of Fe and Mn uptake of former coal mine land. J. Degrad. Min. Lands Manag. 2018, 6, 1527-1537. [CrossRef]

99. Midega, C.A.O.; Wasonga, C.J.; Hooper, A.M.; Pickett, J.A.; Khan, Z.R. Drought-tolerant Desmodium species effectively suppress parasitic striga weed and improve cereal grain yields in western Kenya. Crop. Prot. 2017, 98, 94-101. [CrossRef]

100. Hasanah, N.I.; Wasis, B.; Mansur, I. Desmodium spp. development as cover crop plant on post mining land rehabilitation. J. Silvikultur Trop. 2014, 5, 7-12.

101. Magdoff, F.; Van Es, H. Building Soils for Better Crops: Sustainable Soil Management, 3rd ed.; Sustainable Agriculture Research and Education: College Park, MD, USA, 2009.

102. Angeles, M.D.; Cuevas, V.C. Phytoremediation potential of Paspalum conjugate Berg. and the role of compost amendment in rehabilitation of soil materials from high copper-containing mine tailings ponds. Philipp. Agric. Sci. 2018, 101, $206-215$.

103. Zhang, L.; Zhang, P.; Yoza, B.; Liu, W.; Liang, H. Phytoremediation of metal-contaminated rare-earth mining sites using Paspalum conjugatum. Chemosphere 2020, 259, 127280. [CrossRef] [PubMed]

104. Pandey, V.C.; Singh, A.K. Saccharum spp.-Potential role in ecorestoration and biomass production. In Phytoremediation Potential of Perennial Grasses; Elsevier: Amsterdam, The Netherlands, 2020; pp. 211-226. [CrossRef]

105. Babi, K.; Guittonnya, M.; Larocqueb, G.R.; Bussièrea, B. Effects of spacing and herbaceous hydroseeding on water stress exposure and root development of poplars planted in soil-covered waste rock slopes. Ecoscience 2019, 26, 149-163. [CrossRef]

106. Anshari, M.F.; Boedianto, E.; Fernandes, A.A.R.; Arisoesilaningsih, E. Hydroseeding application using pioneer local plant seeds for coal post-mining soil in Tanah Laut Regency, South Kalimantan. J. Degrad. Min. Lands Manag. 2018, 5, 1335-1345. [CrossRef]

107. Bargawa, W.S.; Putra, A.; Nurcholis, M. Analysis of erosion using hydroseeding on post coal mining in Melak site. Int. J. Geomate 2019, 17, 371-377. [CrossRef]

108. Gastauer, M.; Silva, J.R.; Caldeira, C.F., Jr.; Ramos, S.J.; Filho, P.W.M.S.; Neto, A.E.F.; Siquera, J.O. Mine land rehabilitation: Modern ecological approaches for more sustainable mining. J. Clean. Prod. 2018, 172, 1409-1422. [CrossRef]

109. Novianti, V.; Marrs, R.H.; Choesin, D.N.; Iskandar, D.T.; Suprayogo, D. Natural Regeneration on land degraded by coal mining in tropical climate: Lesson for ecological restoration in Indonesia. Land Degrad. Dev. 2018, 29, 4050-4060. [CrossRef]

110. Józefowska, A.; Pietrzykowski, M.; Wos, B.; Cajthaml, T.; Frouz, J. The efects of tree species and substrate on carbon sequestration and chemical and biological properties in reforested post-mining soils. Geoderma 2017, 292, 9-16. [CrossRef]

111. Zhao, B.; Guo, D.; Shao, H.; Bai, Z. Investigating the population structure and spatial pattern of restored forests in an opencast coal mine, China. Environ. Earth Sci. 2017, 20, 679. [CrossRef]

112. Prasetyo, R.B.; Marisa, H.; Sarno. Vegetation analysis on reclamation area of coal mine of PT. Bukit Asam Tanjung Enim, South Sumatera. Bioval. Biol. Res. J. 2017, 3, 52-59. [CrossRef]

113. Hapsari, L.; Trimanto; Budiharta, S. Spontaneous plant recolonization on reclaimedpost-coal mining sites in East Kalimantan, Indonesia: Native versus alien and succession progress. Biodiversitas 2020, 21, 2003-2018. [CrossRef]

114. Yusuf, M.; Arisoesilaningsih, E. Exotic plant species attack revegetation plants in post-coal mining areas. AIP Conf. Proc. 8th Int. Conf. Glob. Resour. Conserv. 2017, 1908, 1-5. [CrossRef]

115. Pietrzykowski, M. Rehabilitation and reconstruction of terrestrial ecosystems on mine sites-Ecological effectiveness assessment. In Energy Science and Technology Series, Coal Energy; Govil, J.N., Ed.; Studium Press LLC: New Delhi, India, 2015; pp. $121-151$.

116. Komara, L.L.; Choesin, D.N.; Syamsudin, T.S. Plant diversity after sixty years post coal mining in East Kalimantan, Indonesia. Biodiversitas 2016, 2016, 531-538.

117. Komara, L.L.; Murtinah, V.; Arbain. Evaluation of plant species composition after thirteen years post coal mining rehabilitation in East Kutai District of East Kalimantan, Indonesia. IOP Conf. Ser. Earth Environ. Sci. 2018, 144, 1-8. [CrossRef]

118. Sasmita, N.; Liris, K.; Purba, J. Adaptation of pioneer plant at the coal mining area in East Kalimantan Indonesia. J. Comput. Theor. Nanosci. 2020, 17, 750-754. [CrossRef]

119. Trimanto; Sofiah, S. Exploration of flora diversity and recommending species for reclamation of coal mining with biodiversity concept in Besiq Bermai forest, East Borneo. J. Trop. Life Sci. 2018, 8, 97-107. [CrossRef] 
120. Marrs, R.H.; Bradshaw, A.D. Primary succession on man-made wastes: The importance of resource acquisition. In Primary Succession on Land; Miles, J., Walton, D.H., Eds.; Blackwell Publishing: Oxford, UK, 1993.

121. Agus, C.; Pradipa, E.; Wulandari, D.; Supriyo, H.; Saridi; Herika, D. Role of revegetation on the soil restoration in rehabilitation areas of tropical coal mining. J. Mns. Lingkung. 2014, 21, 60-66.

122. Adman, B.; Hendrarto, B.; Sasongko, D.P. Pemanfaatan jenis pohon lokal cepat tumbuh untuk pemulihan lahan pasca tambang batubara (Studi Kasus di PT. Singlurus Pratama, Kalimantan Timur). J. Ilmu Lingkung. 2012, 10, 19-25. [CrossRef]

123. Rizal, A.; Kissinger. Analisis keberhasilan revegetasi pasca tambang batubara di pd. baramarta kabupaten banjar provinsi Kalimantan Selatan. J. Sylva Sci. 2020, 3, 13-25.

124. Ren, H.; Yang, L.; Liu, N. Nurse plant theory and its application in ecological restoration in lower subtropics in China. Prog. Nat. Sci. 2008, 18, 137-142. [CrossRef]

125. Heidelberg, A.; Neunner, H.; Osepashvili, I.; Ilia Schulzke, R. Forest Restoration Guidelines; WWF-Caucasus Programme Office: Berlin, Deutschland, 2011.

126. Swab, R.M.; Lorenz, N.; Byrd, S.; Dick, R. Native vegetation in rehabilitation: Improving habitat and ecosystem function through using prairie species in mine land rehabilitation. Ecol. Eng. 2017, 108, 525-536. [CrossRef]

127. Lestari, D.A.; Fiqa, A.P.; Fauziah, F.; Budiharta, S. Growth evaluation of native tree species planted on post coal mining reclamation site in East Kalimantan, Indonesia. Biodiversitas 2019, 20, 134-143. [CrossRef]

128. Akbar, A.; Priyanto, E.; Basiang, H.A. Potensi tanaman revegetasi lahan reklamasi bekas tambang batubara dalam mendukung suksesi alam. J. Penelit. Hutan Tanam. 2005, 2, 133-140. [CrossRef]

129. Soendjoto, M.A.; Dharmono; Mahrudin; Riefani, M.K.; Triwibowo, D. Plant richness after revegetation on the reclaimed coal mine land of PT. Adaro Indonesia, South Kalimantan. J. Trop. For. Manag. 2014, 20, 142-150. [CrossRef]

130. Mukhtar, A.S.; Heriyanto, N.M. Keadaan suksesi tumbuhan pada kawasan bekas tambang batubara di Kalimantan Timur. J. Penelit. Hutan Konserv. Alam 2012, 9, 341-350. [CrossRef]

131. Iskandar, I.; Suwardi, S. Meningkatkan keberhasilan reklamasi lahan bekas tambang. In Proceedings of the Seminar Nasional Pengelolaan Lingkungan Pertambangan, Lembaga Penelitian Universitas Sriwijaya, Palembang, Indonesia, 21-22 October 2009.

132. Pietrzykowski, M. Soil and plant communities development and ecological effectiveness of rehabilitation on a sand mine cast. $J$. For. Sci. 2008, 54, 554-565. [CrossRef]

133. Zipper, C.E.; Burger, J.A.; Skousen, J.G.; Angel, P.N.; Barton, C.D.; Davis, V.; Franklin, J.A. Restoring forests and associated ecosystem services on appalachian coal surface mines. Environ. Manag. 2011, 47, 751-765. [CrossRef] [PubMed]

134. Mansur, I.; Kadarisman, M.I. Teknik pembibitan kayu putih (Melaleuca Cajuputi) secara vegetatif di persemaian perusahaan batubara PT bukit asam (Persero) Tbk. J. Silvikultur Trop. 2019, 10, 21-28.

135. Rachmat, H.H.; Subiakto, A. Conserving the previously reported extinct tree species Dipterocarpus cinereus: An ex-situ approach for the species conservation strategy. Pros. Sem. Nas. Masy. Biodivers. Indones. 2015, 1, 560-564. [CrossRef]

136. Subiakto, A.; Rachmat, H.H.; Sakai, C. Choosing native tree species for establishing man-made forest: A new perspective for sustainable forest management in changing world. Biodiversitas 2016, 17, 620-625. [CrossRef]

137. Susilowati, A.; Hartini, K.S.; Rachmat, H.H.; Alvaroby, M. Propagation of valuable north sumatera benzoin trees (Styrax Sp.) using macrocutting technique. IOP Conf. Ser. Mater. Sci. Eng. 2017, 180, 012046. [CrossRef]

138. Rachmat, H.H.; Subiakto, A.; Susilowati, A. Mass vegetative propagation of rare and endangered tree species of Indonesia by shoot cuttings by KOFFCO method and effect of container type on nursery storage of rooted cuttings. Biodiversitas 2018, 19, 2353-2358. [CrossRef]

139. Susilowati, A.; Rachmat, H.H.; Kholibrina, C.R.; Hartini, K.S.; Ramb, H.A. Propagation for conserving endangered taxol producing tree Taxus sumatrana through shoot cuttings technique. IOP Conf. Ser. J. Phys. 2019, 1282, 012110. [CrossRef]

140. Siregar, I.Z.; Kustiyarini, N.F.; Wati, R.; Rachmat, H.H.; Siregar, U.J.; Dwiyanti, F.G. Vegetative propagation of Dryobalanops sumatrensis and Dryobalanops oblongifolia subsp. oblongifolia by shoot cuttings. IOP Conf. Ser. Earth Environ. Sci. 2019, $394,012029$. [CrossRef]

141. Rachmat, H.H.; Fambayun, R.A.; Yulita, K.S.; Susilowati, A. Ex-situ conservation and management of dipterocarps genetic resources through seedlings collections and nursery establishment. Biodiversitas 2020, 21, 2085-4722. [CrossRef]

142. Oklima, A.M.; Sudarsono; Iskandar; Suryaningtyas, D.T. Utilizing Coal Ash and Humic Substances as Soil Ameliorant on Reclaimed Post-Mining Land. Soils. J. Trop. Soils 2014, 19, 161-169. [CrossRef]

143. Budiana, I.G.E.; Jumani; Biantari, M.P. Evaluasi tingkat keberhasilan revegetasi lahan bekas tambang batubara di PT Kitadin Site Embalut Kabupaten Kutai Kartanegara Kalimantan Timur. J. Agrifor 2017, 16, 195-208. (In Indonesian)

144. Karlicik, V.; Curcuz, V.G.; Raicevic, V. The alleviation of reforestation challenges by beneficial soil microorganisms. Reforesta 2016, $1,238-260$.

145. Setiadi, Y.; Setiawan, A. Study of arbuscular mycorrhizal fungi status at rehabilitation post-nickel mining area (case study at PT INCO Tbk Sorowaoko, South Sulawesi). J. Silvikutur Trop. 2011, 3, 88-95.

146. Prayudyaningsih, R.; Sari, R.; Mangopang, A.D. Isolation of Iindigenous arbuscular mycorrhizal fungi (AMF) to support revegetation on the nickel post-mining land. IOP Conf. Ser. Earth Environ. Sci. 2019, 308. [CrossRef]

147. Salim, M.A.; Budi, S.W.; Setyaningsih, L.; Iskandar; Kirmi, H. Diversity of arbuscular mycorrhizal fungi as affected by time consequences revegetation age in post coal mine area at PT Berau Coal Tbk, East Kalimantan Indonesia. IOP Conf. Ser. Earth Environ. Sci. 2019, 394, 012067. [CrossRef] 
148. Ulfa, M.; Kurniawan, A.; Sumardi; Sitepu, I. Population of indigenous Arbuscular Mycorrhizal Fungi (AMF) in post coal-mining land. J. Penelit. Hutan Konserv. Alam 2011, 8, 301-309. [CrossRef]

149. Akib, M.A.; Mustari, K.; Kuswinanti, T.; Syaiful, S.A. Abundance of arbuscular mychorrizal fungi in rehabilitation area of nickel post-mining land of Sorowako, South Sulawesi. IOP Conf. Ser. Earth Environ. Sci. 2018, 157. [CrossRef]

150. Turjaman, M.; Santoso, E.; Sitepu, I.R.; Tawaraya, K.; Purnomo, E.; Tambunan, R.; Osaki, M. Mycorrhizal fungi increased early growth of tropical tree seedlings in adverse soil. Indones. J. For. Res. 2009, 6, 17-25. [CrossRef]

151. Wulandari, D.; Saridi; Cheng, W.; Tawaraya, K. Arbuscular mycorrhizal fungal inoculation improves Albizia saman and Paraserianthes falcataria growth in post-opencast coal mine field in East Kalimantan, Indonesia. For. Ecol. Manag. 2016, 376 , 67-73. [CrossRef]

152. Prematuri, R.; Turjaman, M.; Tawaraya, K. Effect of arbuscular mycorrhiza fungal inoculation on growth of tropical tree species under nursery and post-opencast bauxite mining field in Bintan Island, Indonesia. Int. J. Plant. Soil Sci. 2020, 32, 1-13. [CrossRef]

153. Setyaningsih, L.; Dikdayatama, F.A.; Wulandari, A.S. Arbuscular mycorrhizal fungi and Rhizobium enhance the growth of Samanea saman (Trembesi) planted on gold-mine tailings in Pongkor, West Java, Indonesia. Biodiversitas 2020, 21, 611-616. [CrossRef]

154. Budi, S.W.; Wibowo, C.; Sukendro, A.; Bekti, H.S. Growth improvement of Falcataria moluccana inoculated with mycosilvi grown in post-mining silica sand soil medium amended with soil ameliorants. Biodiversitas 2020, 21, 422-427.

155. Akib, M.A.; Mustari, K.; Kuswinanti, T.; Syaiful, S.A.; Kumalawati, Z.S. Nickel (Ni) reduction in Sorowako post-mining soil through application of mycorrhiza Acaulospora sp. associated with Canavalia ensiformis L. J. Microb. Syst. Biotechnol. 2019, 1, 30-37. [CrossRef]

156. Tuheteru, F.D.; Arif, A.; Husna; Mansur, I.; Tuheteru, E.J.; Jusniar; Basrudin; Albasri; Hadijah, M.H.; Karepesina, S. Arbuscular mycorrhizal fungal inoculation improves Nauclea orientalis L. growth and phosphorus uptake in gold mine tailing soil media. $J$. Degrad. Min. Lands Manag. 2020, 7, 2193-2200. [CrossRef]

157. Ghaida, S.H.; Wasis, B.; Budi, S.W. Application of arbuscular mycorrhizal fungi and soil ameliorant on the growth of Leucaena leucocephala in limestone post-mining soil media. J. Manaj. Hutan Trop. 2020, 26, 282-290. [CrossRef]

158. Sari, R.; Prayudyaningsih, R. The role of indigenous Rhizobia on Paraserianthes falcataria (L) Nielsen seedlings in nickel post mining lands. IOP Conf. Ser. Earth Environ. Sci. 2019, 308, 1-9. [CrossRef]

159. Prayudyaningsih, R. The role of indigenous Arbuscular Mycorrhizal Fungi (AMF) to the growth of Bitti (Vitex cofassus Reinw.) and soil chemical properties improvement on reclamation of limestone post mining land in south Sulawesi. In Promoting Sustainable Resources from Plantation for Economic Growth and Community Benefits, Proceeding of IUFRO_INAFOR Joint International Conference, Jogjakarta, Indonesia, 24-27 July 2017; Ministry of Environment and Forestry Research Development and Innovation Agency: Bogor, Indonesia, 2017; pp. 319-324.

160. Ekamawanti, H.A.; Setiadi, Y.; Sopandie, D.; Santoso, D.A. The role of arbuscular mycorrhizal fungus (Gigaspora margarita) on mercury and nutrients accumulation by Enterolobium cyclocarpum. Microbiol. Indones. 2013, 7, 167-176. [CrossRef]

161. Seguel, A.; Cumming, J.R.; Klugh-Stewart, K.; Cornejo, P.; Borie, F. The role of arbuscular mycorrhizas in decreasing aluminium phytotoxicity in acidic soils: A review. Mycorrhiza 2013, 23, 167-183. [CrossRef] [PubMed]

162. Barua, A.; Gupta, S.D.; Mridha, M.A.U.; Bhuiyan, M.K. Effect of arbuscular mycorrhizal fungi on growth of Gmelina arborea in arsenic contaminated soil. J. For. Res. 2010, 21, 423-432. [CrossRef]

163. Hovsepyan, A.; Greipsson, S. Effect of arbuscular mycorrhizal fungi on phytoextraction by corn (Zea mays) of lead-contaminated soil. Int. J. Phytoremediation 2004, 6, 305-321. [CrossRef]

164. Rollon, R.J.C.; Galleros, J.E.V.; Galos, G.R.; Villasica, L.J.D.; Carcia, C.M. Growth and nutrient uptake of Paraserianthes falcataria (L.) as affected by carbonized rice hull and arbuscular mycorrhizal fungi grown in an artificially copper contaminated soil. $A A B$ Bioflux 2017, 9, 57-67.

165. Sourková, M.; Frouz, J.; Šantrùčková, H. Accumulation of carbon, nitrogen and phosphorus during soil formation on alder spoil heaps after brown-coal mining, near Sokolov (Czech Republic). Geoderma 2005, 124, 203-214. [CrossRef]

166. Maharana, J.K.; Patel, A.K. Physico-chemical characterization and mine soil genesis in age series coal mine overburden spoil in chronosequence in a dry tropical environment. J. Phylogenet. Evol. Biol. 2013, 1, 101. [CrossRef]

167. Mukhopadhyay, S.; Maiti, S.K.; Masto, R.E. Development of mine soil quality index (MSQI) for evaluation of reclamation success: A chronosequence study. Ecol. Eng. 2014, 71, 10-20. [CrossRef]

168. Oktaviani, E.; Susanto, D. Effect of inoculant rhizobium and compost as amelioration on growth of peanut Arachis hypogaea in soil post-coal mining. Int. J. Sci. Technol. Res. 2017, 4, 1-5.

169. Nurhikmah, P.I.; Kusumawati, E.; Susanto, D. Effect of vesicular-arbuscular mycorrhizae inoculation and liquid organic fertilizer application to the phosphorus concentration on soybean (Glycine max L.) in soils post-coal mining. Int. J. Sci. Technol. Res. 2018, 7, 110-112.

170. Duaja, M.D.; Kartika, E.; Lizawati. Application of indigenous AMF from ex-coal mining soil combined with phosphorus fertilizers to improve oil palm seedling growth (Elaeis guineensis Jacq.). Biogenesis 2019, 7, 38-43. [CrossRef]

171. Syafria, H.; Jamarun, N.; Pazla, R. Utilization of biourine and arbuscular mycorrhizal fungi as biotechnological agents for improving land productivity of ex-coal mines and testing their effects on the content of forage fiber fractions [Hymenachne amplexicaulis (Rudge) Nees]. Pak. J. Nutr. 2019, 18, 791-794. [CrossRef] 
172. Agus, C.; Wulandari, D.; Primananda, E.; Hendryan, A.; Harianja, V. The role of soil amendment on tropical post mining area in Bangka island Indonesia for dignified and sustainable environment and life. IOP Conf. Ser. Earth Environ. Sci. 2017, 83, 1-8. [CrossRef]

173. Lestari, T.; Apriyadi, R.; Amandha, G. Growth and yield of edamame soybean in post-tin mining land with application of Rhizobium bacteria and organic fertilizer. IOP Conf. Ser. Earth Environ. Sci. 2021, 694, 012038. [CrossRef]

174. Perala, I.; Wulandari, A.S. Kayu Kuku (Pericopsis mooniana Thw.) seedlings growth response to tailing media added with vermicompost, rhizobium, and arbuscular mycorrhizal fungi. IOP Conf. Ser. Earth Environ. Sci. 2019, 394. [CrossRef]

175. Mansur, I. Teknik Silvikultur Untuk Reklamasi Lahan Bekas Tambang; Seameo Biotrop: Bogor, Indonesia, 2010. (In Indonesia)

176. Nugroho, Y. Aplikasi silvikultur intensif untuk pertumbuhan tanaman pengayaan pada lahan reklamasi tambang batubara. $J$. Hutan Trop. 2015, 3, 241-246.

177. Susilo, A. Planting trial of five dipterocarp species on ex-coal mining land in PT. Kitadin, Kalimantan Timur. Proc. Biol. Educ. Conf. 2016, 13, 672-676.

178. Alkad, E.; Kasim, T.; Yunasril. Perencanaan Dan Biaya Reklamasi Lahan Bekas Tambang Area Tambang Batubara PT. Baturona Adimulya Desa Supat Barat Kecamatan Babat Supat Kabupaten Musi Banyuasin. J. Bina Tambang 2014, 3, $1262-1274$.

179. Aryadi, M.; Fauzi, H. Perception and aspiration of community and local wisdom for revegetation activities at ex-coal mined area (Study on Dusun Beliaspa, Batang Banyu Village, Banjar Regency). Hutan Trop. 2012, 13, 92-100.

180. Rusdiana, O.; Setiadi, A. The evaluation of the success of plant revegetation in post coal mining block M1W. J. Silvikultur Trop. 2019, 10, 125-132.

181. Isnaini, M.N.; Soendjoto, M.A. Riap diamater dari tanaman non-legum di area reklamasi dan revegtasi PT Adaro Indonesia, Provinsi Kalimantan Selatan, Indonesia Kalimantan Selatan Province, Indonesia. J. Sylva Sci. 2019, 2, 1133-1139.

182. Abadi, M.R.; Winarno, E. Rencana Biaya Reklamasi Program Pascatambang lahan bekas tambang pasir kuarsa di PT Tri panorama Setia Kecamatan Kijang Kabupaten Bintan Provinsi Kepulauan Riau. J. Teknol. Pertamb. 2017, 3, 150-158.

183. Setiadi, Y.; Putri, N. Evaluation of the success result plants revegetation in coal post-mining land Lati Site PT Berau Coal East Kalimantan. J. Silvikultur Trop. 2013, 4, 77-81.

184. Adman, B.; Nugroho, A.W.; Yassir, I. The growth of local tree species on post-coal mining areas in east kalimantan. Indones. J. For Res. 2020, 7, 83-97. [CrossRef]

185. Toumbouroua, T.; Muhdar, M.; Wernera, T.; Bebbington, A. Political ecologies of the post-mining landscape: Activism, resistance, and legal struggles over Kalimantan's coal mines. Energy Res. Soc. Sci. 2020, 65, 101476. [CrossRef]

186. Negara, T.; Kusmana, C.; Mansur, I.; Santi, N.A.; Jaya, I.N.S. Identifying the key variables for assessing the reclamation success on early growth. J. Manaj. Hutan Trop. 2020, 25, 222-232. [CrossRef]

187. Erener, A. Remote sensing of vegetation health for reclaimed areas of Seyitömer open cast. Int. J. Coal Geol. 2011, 86, 20-26. [CrossRef]

188. Buczyńska, A. Remote sensing and GIS technologies in land reclamation and landscape planning processes on post-mining areas in the Polish and world literature. AIP Conf. Proc. 2020, 2209, 040002. [CrossRef]

189. McKenna, P.B.; Lechner, A.M.; Phinn, S.; Erskine, P.D. Remote sensing of mine site rehabilitation for ecological outcomes: A global systematic review. Remote Sens. 2020, 12, 3535. [CrossRef]

190. Soendjoto, M.A.; Riefani, M.K.; Triwibowo, D.; Metasari, D. Birds observed during the monitoring period of $2013-2017$ in the revegetation area of ex-coal mining sites in South Kalimantan, Indonesia. Biodiversitas 2018, 19, 323-329. [CrossRef]

191. Rayadin, Y.; Ayatussurur, M.; Pradesta, H.; Pratama, A.A.; Maharani, R. Kawasan Konservasi Multifungsi di PT Jembayan Muara Bara; PT Ecositrop: Samarinda, Indonesia, 2020.

192. Rayadin, Y.; Ayatussurur, M.; Pradesta, H.; Pratama, A.A.; Maharani, R. Kawasan Konservasi Multifungsi di PT Kideco Jaya Agung; PT Ecositrop: Samarinda, Indonesia, 2020.

193. Rayadin, Y.; Ayatussurur, M.; Pradesta, H.; Pratama, A.A.; Maharani, R. Kawasan Konservasi Multifungsi di PT Multi Harapan Utama; PT Ecositrop: Samarinda, Indonesia, 2020.

194. Pranoto, K.; Febrianto, A.; Ikhsan, M.Z.; Wahyudi, E.; Sudrajat, J. Utilization of ex-mining pits (voids) as a source of water in the Jupiter pit PT Kaltim Prima Coal. In Proceedings of the Annual Scientific Meeting XXXV HATHI, Medan, Indonesia, 7-9 September 2018.

195. Tuheteru, E.J.; Gautama, R.S.; Kusuma, G.J.; Pranoto, K. Pit lake sebagai alternatif kegiatan pascatambang (Hasil Review Pustaka). In Proceedings of the Prosiding XXVII dan Kongres X Perhapi, Jakarta, Indonesia, 30 October-1 November 2018.

196. Santoso, A.D.; Setiawan, A. Why is the $\mathrm{pH}$ of ex-mining ponds relatively stable? Case Study on Solar Pond and Sangatta North in Areal of PT KPC Sangatta Kalimantan Timur. J. Hidrosfir Indones. 2009, 4, 9-15.

197. Caesarina, H.M.; Hirsan, F.P. Danau Seran, a pit lake in an ex-mining area as an opportunity for sustainable tourism. IOP Conf. Ser. Earth Environ. Sci. 2020, 413, 012026. [CrossRef]

198. Haigh, M.; Woodruffe, P.; D'Aucourt, M.; Alun, E.; Wilding, G.; Fitzpatrick, S.; Filcheva, E.; Noustorova, M. Successful ecological regeneration of opencast coal mine spoils through forestation: From cradle to grove. Minerals 2020, 10, 461. [CrossRef]

199. Rayadin, Y.; Pradesta, H.; Hadiyana, I. Keanekaragaman Jenis Mamalia di Kawasan Reklamasi dan Pascatambang PT Kideco Jaya Agung; Pustaka Tropis: Bandung, Indonesia, 2020. 
200. Suba, R.B. Kehadiran jenis-jenis mamalia di areal reklamasi-rehabilitasi pasca tambang batubara: Respon terhadap perubahan habitat. In Proceedings of the Prosiding Seminar Nasional Taksonomi Fauna Indonesia III, Puslit Biologi LIPI, REA KON, CI and IRATA, Bogor, Indonesia, 10-11 November 2009; pp. 1-16.

201. Rayadin, Y.; Pradesta, H.; Hadiyana, I. Keanekaragaman Jenis Mamalia di Kawasan Reklamasi dan Pascatambang PT Indominco Mandiri; Ecositrop and Indominco Mandiri: Bontang, Indonesia, 2020.

202. Muslim, T. Herpetofauna pada kawasan tambang di Kalimantan Timur. In Reklamasi Lahan Pasca Tambang: Aspek Kebijakan, Konservasi dan Teknologi; Balitek KSDA: Samboja, Indonesia, 2013; pp. 129-178.

203. Boer, C.; Soetedjo; Harmonis; Suba, R.B. Analisis interelasi tumbuhan dan satwa di areal reklamasi-rehabilitasi pasca tambang batubara. In Pusat Penelitian Hutan Tropis (PPHT) Universitas Mulawarman and PT; Kaltim Prima Coal: Samarinda, Indonesia, 2009. 